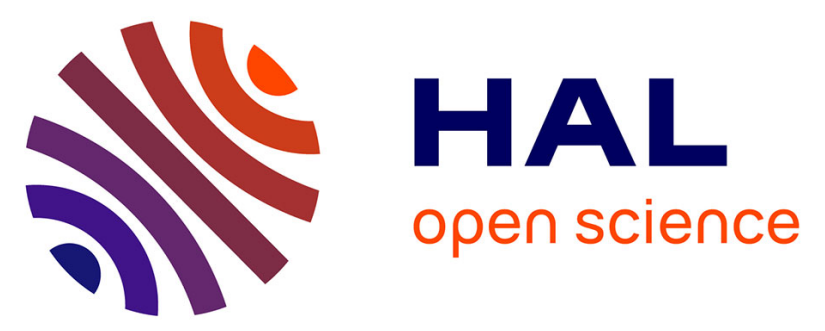

\title{
Upper-plate magma-poor rifted margins: stratigraphic architecture and structural evolution
}

Isabelle Haupert, Gianreto Manatschal, Alessandro Decarlis, Patrick

Unternehr

\section{- To cite this version:}

Isabelle Haupert, Gianreto Manatschal, Alessandro Decarlis, Patrick Unternehr. Upper-plate magmapoor rifted margins: stratigraphic architecture and structural evolution. Marine and Petroleum Geology, 2015, 10.1016/j.marpetgeo.2015.10.020 . hal-01264642

\section{HAL Id: hal-01264642 \\ https://hal.science/hal-01264642}

Submitted on 29 Jan 2016

HAL is a multi-disciplinary open access archive for the deposit and dissemination of scientific research documents, whether they are published or not. The documents may come from teaching and research institutions in France or abroad, or from public or private research centers.
L'archive ouverte pluridisciplinaire HAL, est destinée au dépôt et à la diffusion de documents scientifiques de niveau recherche, publiés ou non, émanant des établissements d'enseignement et de recherche français ou étrangers, des laboratoires publics ou privés. 


\section{Accepted Manuscript}

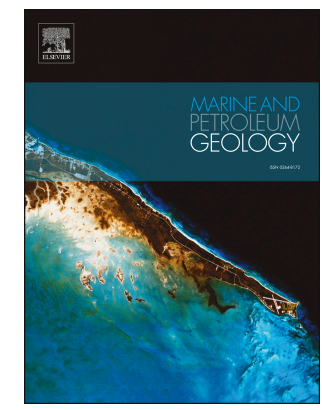

Upper-plate magma-poor rifted margins: stratigraphic architecture and structural evolution

Isabelle Haupert, Gianreto Manatschal, Alessandro Decarlis, Patrick Unternehr

PII:

S0264-8172(15)30121-5

DOI:

10.1016/j.marpetgeo.2015.10.020

Reference:

JMPG 2379

To appear in: $\quad$ Marine and Petroleum Geology

Received Date: 23 June 2015

Revised Date: 21 October 2015

Accepted Date: 26 October 2015

Please cite this article as: Haupert, I., Manatschal, G., Decarlis, A., Unternehr, P., Upper-plate magmapoor rifted margins: stratigraphic architecture and structural evolution, Marine and Petroleum Geology (2015), doi: 10.1016/j.marpetgeo.2015.10.020.

This is a PDF file of an unedited manuscript that has been accepted for publication. As a service to our customers we are providing this early version of the manuscript. The manuscript will undergo copyediting, typesetting, and review of the resulting proof before it is published in its final form. Please note that during the production process errors may be discovered which could affect the content, and all legal disclaimers that apply to the journal pertain. 


\section{Upper-plate magma-poor rifted margins: stratigraphic architecture and structural evolution}

Isabelle Haupert ${ }^{1}$, Gianreto Manatschal ${ }^{1}$, Alessandro Decarlis ${ }^{1}$ and Patrick Unternehr ${ }^{2}$

${ }^{1}$ IPGS/EOST, Université de Strasbourg, rue Blessig 1, F-67084 Strasbourg Cedex, France

2 TOTAL- Exploration Production/Projets Nouveaux place Jean Millier, La Défense 6, 92078 Paris la Defense Cedex, France

Corresponding author : haupert@unistra.fr

Research highlights

- generic model to describe architecture and evolution of upper plate magma-poor rifted margins

- linking the stratigraphic, isostatic and structural evolution during rifting

- comparison between fossil and present-day margins enables to up and down-scale observations

Key words : upper plate magma-poor rifted margins, hyper-extension, tectono-stratigraphic evolution, crustal architecture, Ocean-Continent Transition

\section{Abstract}

Although it is generally accepted that many distal, magma-poor rifted margins are asymmetric and can be divided into lower and upper plate margins, little is known about the details of how and when this asymmetry evolves and how upper and lower plate margins can be distinguished. This is due to the fact that most papers focused on the so called lower plate margins, while the upper plate margins remained less well understood, mainly due to the lack of public accessible drill hole data. The aim of this paper is to provide a first order description of the global architecture and stratigraphic evolution of an upper plate, magma-poor rifted margin. In order to provide such a template, we focused on 2 seismic sections, the ION-1000 line (East Indian margin), and the SCREECH 2 line (Newfoundland margin) and describe key, km-scale outcrops from the fossil European margin exposed in the Western/Central Alps, all of which document 
classical upper plate margins. Based on these data we show that upper plate magma-poor rifted margins can be characterized by a staircase type architecture with terraces $\left(T_{1}, T_{2}, T_{3}\right)$ and ramps $\left(\mathrm{R}_{1}, \mathrm{R}_{2}\right)$ that result as a consequence of an evolution through a coupling, exhumation and breakup stage. We also defined key stratigraphic levels that we try to link with the evolution of the margin which enables us to link the tectonic evolution with the creation of accommodation space and formation of the staircase architecture that characterizes the upper plate margin. From these observations we develop a conceptual model for the evolution of upper-plate margins and discuss the applicability of this model for different strain rates, rates of subsidence and sedimentation rates.

\section{Introduction}

During the last decades research on rift systems leading to plate separation and formation of oceanic domains went through several paradigm shifts. In the late seventies and early eighties, debates were mostly related to pure- vs. simple-shear models and the question if lithospheric scale detachment faults exist or not. In the late eighties and early nineties, the question about volcanic $v s$. non-volcanic rifting dominated the research on rifted margins. These earlier models were either based on physics (e.g. McKenzie, 1978; Buck, 1991), on field observations (e.g. Basin and Range ; Wernicke, 1981) or some few drill holes and low quality seismic sections. The increasing number of high quality long offset seismic data, mainly due to the increasing interest of industry to explore the deep-water parts of rifted margins, enabled to answer some of these previous questions. Moreover, the development of dynamic modeling enabled to get a better understanding of the crustal-scale processes and to test some of the basic assumptions made in extensional tectonics. Key questions addressed at present are related to the coupling/decoupling 
between crust and mantle and lithosphere and asthenosphere during advanced rifting, the importance of magma and fluids for the evolution of the rheology at the transition from rifting to seafloor spreading, and the relationships between extension and creation of accommodation space in time and space in hyper-extended systems. In order to find answers to these questions, some of the basic assumptions of extensional systems that form the foundation of existing models need to be scrutinized and new interpretations are necessary to explain some of the fundamental observations made in the new data sets.

The aim of this paper is to describe the first order stratigraphic architecture and structural evolution of so called "upper plate" magma-poor rifted margins. We focus on three examples that we consider as typical upper-plate magma-poor rifted margins: one fragmented during Alpine collision, but partly exposed in the Western and Central Alps in Western Europe, one seismically imaged offshore eastern India, and a last one seismically imaged and drilled offshore Newfoundland. Because none of the 3 examples provides a complete dataset and cannot therefore be used to explain the detailed relationship between extension and creation of accommodation space, we integrate the different observations/data in a "type" section in order to define and discuss the first order tectono-stratigraphic evolution of upper plate margins. Initial assumptions that are made in this study are that: 1) margins show first order architectural characteristics and processes that can be found and described, and 2) the "type" section proposed here represents an idealized, non-unique section, which does not exist in nature, but includes the key building blocks and structural and stratigraphic relationships that characterize upper plate, magma-poor rifted margins. We are aware that our approach suffers of some limitations that are important to consider when the results and concepts established here are used to describe a margin with a defined history and inheritance. The main limitations are to: 1) not consider the nature of the 
sediments filling the accommodation space, 2) to limit to magma-poor systems, and 3) to ignore the geological inheritance and the 3D lateral architecture of a margin segment, which is related to a variability of the large-scale structure along strike. Indeed, the described characteristics may vary along strike and may therefore also be geographically dependent. Thus, rather than to explain a detailed description of one particular upper plate margin, here we try to develop a conceptual framework to make first order descriptions and predictions of the structural and stratigraphic evolution of an upper plate, magma-poor rifted margin. The idea is to create a template and to develop a methodology to recognize and interpret magma-poor, upper plate rifted margins.

\section{Models, concepts, terminology and methodology}

\subsection{Development of models and concepts}

The description of rift systems is strongly linked to two end-member models, the McKenzie (1978) and Wernicke (1981) models that describe two fundamental different ways of how strain is partitioned in the crust and lithosphere. The McKenzie model is depth-uniform and symmetric, assuming that crustal and lithospheric thinning is inversely proportional to horizontal extension. On the contrary the Wernicke model is more conceptual and assumes that deformation in the crust and lithosphere is coupled and fundamentally asymmetric. Based on observations in the Basin and Range and at rifted margins, Lister et al. (1986) proposed a rift model that accounts for a "lower-plate" and an "upper-plate" margin (Fig. 1a). Indeed, several authors found similarities between the Basin and Range tectonics and structures observed at passive margins (e.g.Buck et al., 1988; Pubellier and Ego, 2002; Pubellier et al., 2003). In particular, extensional detachment 
faults, similar to those well exposed in the Basin and Range, have also been recognized along present-day and fossil rifted margins (Masini et al., 2012 and references in there). Such faults are associated with the formation of metamorphic core-complexes (Crittenden et al., 1980) in the footwall (i.e. the "lower plate") while their hanging wall, (i.e. the "upper plate") is considered as largely brittle and less deformed (Reynolds and Spencer, 1985). However, it's important to note that the hanging-wall is still affected by extensional structures including normal faults and associated shear zones in more ductile crustal levels. In contrast to the McKenzie model that can successfully explain the structural style of North Sea type rift systems, the "upper-lower plate" model of Lister et al. (1986) was used to explain some first order observations made at presentday rifted margins (Fig.1a). Typically, the Lister model accounts for wide vs. narrow conjugate margins, exhumation of mantle rocks and contrasting subsidence histories observed at both margins. 
(a)

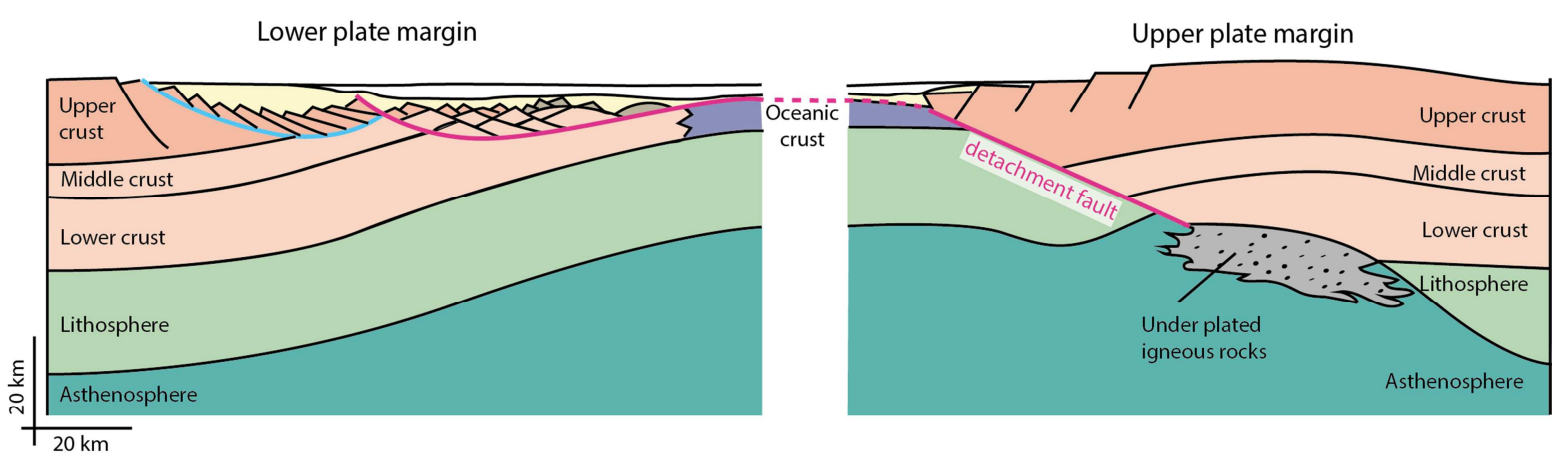

(b)

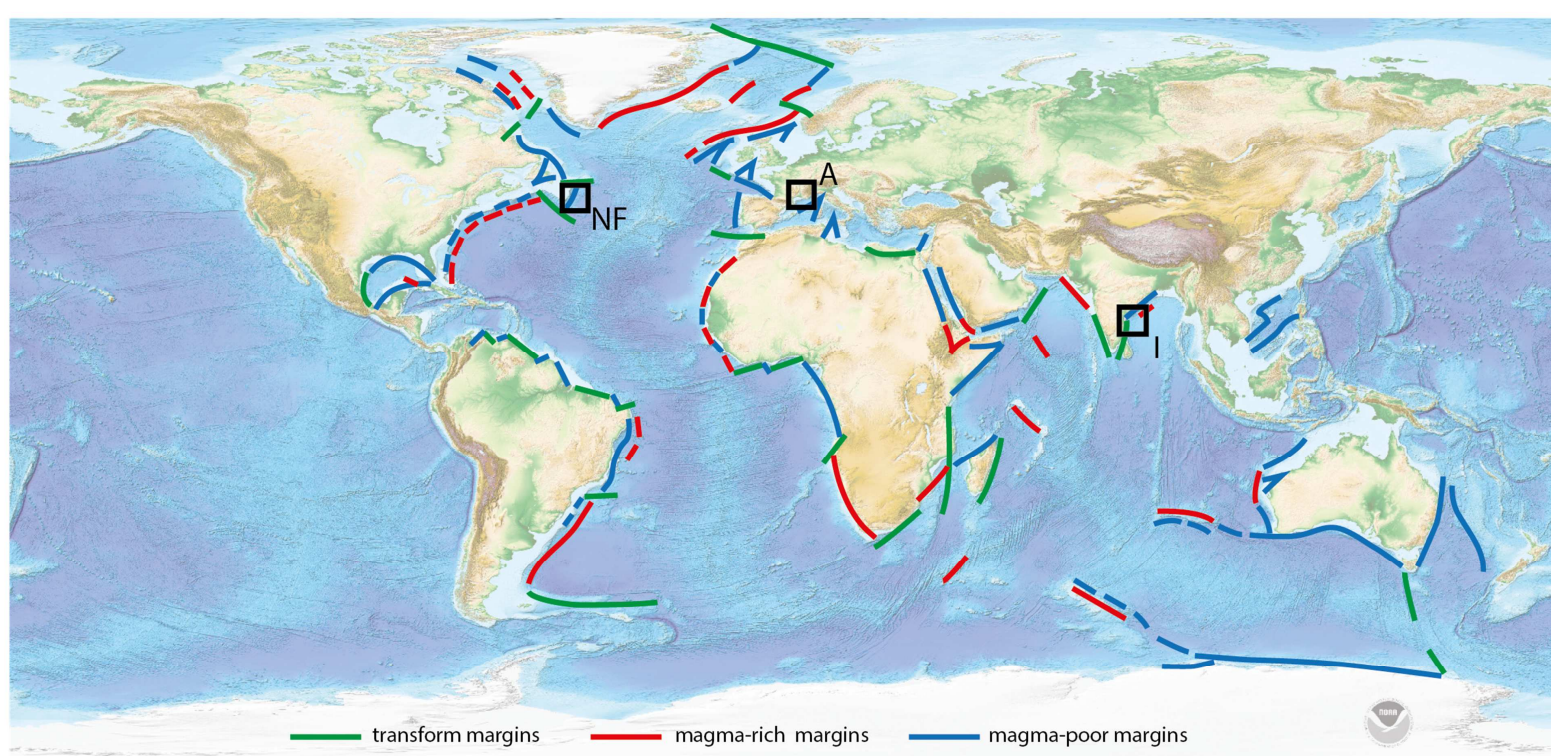

Fig.1 a) The classical "Upper-Lower plate" model proposed by Lister et al. (1986) with key characteristics of the two conjugate margins separated by a lithospheric scale detachment-fault. b) Bathymetrictopographic map of the world (map from National Geophysical Data Center) showing the distribution of magma-poor, magma-rich and transform margins. Transform margins can also be classified as magmapoor or magma-rich, however, the present state of knowledge about these margins is meager and prevent such a classification at the moment. Black squares localize the sites discussed in this paper $(A=A l p s$, $\mathrm{I}=$ East Indian margin, $\mathrm{NF}=$ Newfoundland margin) .

The archetypal examples of asymmetric, magma-poor rifted margins became the IberiaNewfoundland conjugate margins (Boillot et al., 1987) and the Alpine Tethys margins exposed in 
the Alps (Lemoine et al., 1987). However, since the "upper-lower plate" model of Lister was intimately linked to the Wernicke model, i.e. to Basin and Range tectonics and to low-angle extensional detachment faults that violate first order mechanical principles, many researchers discarded this model. Moreover, since most of the rift basins located at the proximal domains at conjugate rifted margins look relatively symmetrical and can be explained by pure shear, Driscoll and Karner (1998) introduced the so-called "upper-plate" paradox. Nevertheless, Huismans and Beaumont (2002) showed that the capacity of an extending crust to couple or decouple deformation on a crustal scale depends, at a first order, on the rates of extension and the rheology or the lithosphere. These parameters therefore have a strong control on the symmetry vs. asymmetry of rifted margins. Recent studies shed a new light on the lateral variation of the architecture of rifted margins. Transitions from magma-poor to magma-rich and changes from upper to lower plate can be observed following rifted margins along strike (see Fig. 1b; ( Reston, 2009, 2007; Franke, 2013; Peron-Pinvidic et al., 2013). Nevertheless, on a first order, it appears that magma-rich rifted margins tend to be more symmetric, while magma-poor systems are typically asymmetric in their distal parts. However, observations and dynamic models show that rifted margins are not the result of a single process and/or event, but of polyphase rift events. Lavier and Manatschal (2006) and Péron-Pinvidic and Manatschal (2009) developed a model in which rift systems go through different stages, referred to as stretching, thinning and exhumation modes before breakup occurs (Fig. 2). Peron-Pinvidic and Manatschal (2010), Sutra et al. (2013) and Tugend et al. (2015) described and characterized "building blocks" and "rift domains" that result from the polyphase evolution and can be used to describe the architecture of magma-poor rifted margins. 


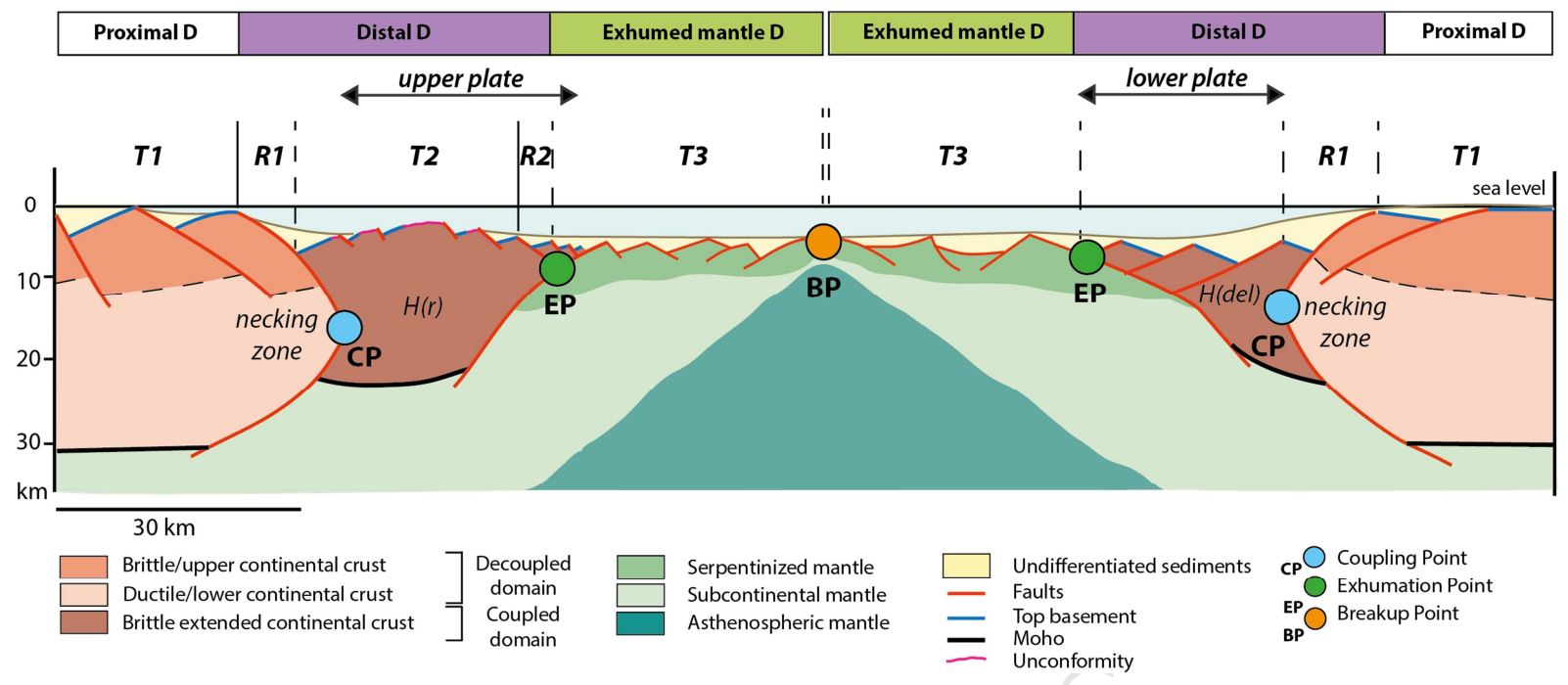

Fig.2 Type section across a magma-poor rifted margin, after the first three stage of deformation (stretching, thinning and exhumation) (modified after Sutra et al., 2013), showing the main terminology used in this paper to describe domains, domain boundaries and crustal blocks. For definition of terms see text.

\subsection{Definition of an "upper-plate" margin}

As mentioned in the previous section, the "upper-plate" concept, as introduced by Lister et al. (1986) (Fig.1a), was strongly linked to the Wernicke model and lithospheric-scale extensional detachment faults. Since the existence of such faults was for a long time a matter of debate, in this study we refine the original "upper-plate" concept in order that it can be used to properly describe the evolution of rifted margins in a much wider context. Using the term "upper-plate" already begs the question: upper-plate to what? In its pristine concept, the term "upper-plate" was used as a synonym of "hanging wall" of a major, lithospheric scale extensional detachment fault. However, in contrast to the Basin and Range, where extensional detachments are exposed, at rifted margins these structures are buried underneath thick sediments, magma and water and are 
split during breakup between the two futures conjugate margins (Fig.1a). The lower plate usually carries remnants of the former hanging-wall (i.e. extensional allochthons or rafts ; (Wernicke, 1981, 1985; Wernicke and Burchfiel, 1982; Davis, 1983). Thus, "upper-plate" does not exclusively refer to the position of a block relative to a major extensional detachment system, but refers to a position in a conjugate magma-poor rifted margin. A second limitation is that "upper" and "lower" do not apply to proximal domains that commonly do not show any asymmetry, neither from the architectural point of view, nor from their subsidence history (Lister et al. 1986; Karner et al. 2003). Therefore the "upper-plate" is limited continental ward by the necking zone, defined by the Coupling Point (CP) and its oceanward position is defined by the Exhumation Point (EP), which is the "hyperextended" portion of the margin (see Fig. 2, and for definition of CP and EP see Sutra et al. 2013 and Tugend et al. 2015). Another characteristic of upper plate margins is the narrower and sharper transition between the continental crust and exhumed mantle and/or oceanic crust. However, in order to safely distinguish, using this characteristic, between upper and lower plate margins, one has to see both conjugate margins. It is often by the comparison of the geometries and widths of the distal domains that one can decide which is the upper plate and which is the lower plate.

In magma-rich systems or in margins with thick sedimentary successions, especially with evaporites, the crustal structure is often masked and it is difficult to define a real asymmetry of the distal parts of the margin. Therefore, interpretations of margins that are not well imaged often suggest that they are, on a global scale, symmetric and that upper and lower plates do not exist (see Péron-Pinvidic et al. 2013; Gillard et al., 2015). Thus, the recognition of upper and lower plate-margins also depends on the quality of the data. 


\subsection{Methodology}

The major problem in defining the tectono-stratigraphic evolution of upper-plate margins is the lack of data. In the ideal case this should include high quality seismic imaging combined with drill hole data. While such a data set exists for lower-plate margins (e.g. Iberia margin; Tucholke and Sibuet, 2007; Sutra et al. 2013) at present it is not available for an upper-plate margin. In this study, we chose three different "upper plate" margins, each one unique and complementary at the same time.

Thanks to the support of ION and in collaboration with industry, we had access to the East-India ION-1000 line (Fig. 3). We consider this line as one of the world best imaged lines across an upper plate magma-poor rifted margin. Unfortunately, no drill-hole data exist from its distal part. At present, drill sites are only localized in the more proximal part and access to these data do not provide insights into the tectono-stratigraphic relationships, type of contacts and rocks imaged in the deeper and more distal parts of the section.

Rocks and contacts that we interpret to have derived from similar settings are exposed in the Western and Central Alps in Western Europe and have been extensively studied (Lemoine and Trümpy, 1987; Roux et al., 1988; Lemoine and Tricart, 1988). Insights coming from such outcrops are a key to understand the evolution and processes controlling the formation of upper plate margins. Unfortunately, the European margin has been reactivated, deformed and partly subducted during the Alpine convergence. Therefore, only remnants of the former margin are preserved, providing only punctual information on the former margin architecture. The integration of these data into an overall picture can either be done by restoring the deformed 
margin, or by comparing it with present-day analogues (Boillot et al. 1987 ; Lemoine et al. 1988 ; Boillot and Froitzheim, 2001; Manatschal and Müntener, 2009).

A hybrid dataset, unique and therefore very important to link the different scales of a magmapoor conjugate margin comes from the Newfoundland margin (Fig. 4). It accounts for refraction and reflection seismic data as well as ODP (Ocean Drilling Project) drill hole data. In this study we focus on the upper plate, which corresponds to the Newfoundland margin (Van Avendonk et al., 2009; Péron-Pinvidic and Manatschal 2009; Sutra et al. 2013). This margin has been imaged by the SCREECH project (Funck et al., 2003; Hopper et al., 2004; Shillington et al., 2006; Van Avendonk et al., 2009) as well as drilled during ODP Leg 210 (ODP drill Sites 1276 and 1277; Hopper et al., 2004).

Based on the observations from the Indian example, which is unique due to the high quality of seismic imaging, the Alpine example due to its superb outcrops and the Newfoundland margin due to the deep drilling (ODP Leg 210), we propose a template for magma-poor, upper-plate rifted margins. In order to up and down-scale the geophysical and geological data, we followed a methodology introduced by Tugend et al. (2015a) and we further develop it to apply it to upperplate margins. The criteria to define rift domains and domain boundaries for the three examples are used following the work of Sutra et al. (2013).

\section{Examples of "upper-plate" magma-poor rifted margins}

\subsection{The East-India ION IE1-1000 line}

\subsubsection{Data and context}


With permission of ION Geophysical, we had access to the ION IE1-1000 section located at the East-India margin (for location see Fig.3). This seismic section is part of the India-Span, a reflection seismic imaging survey that extends between latitude $10^{\circ} \mathrm{N}$ and $21^{\circ} \mathrm{N}$ and longitude $80^{\circ} \mathrm{E}$ and $90^{\circ} \mathrm{E}$ along the East-Indian margin (for more details see Nemcok et al., 2013; Mangipudi et al. 2014). This long offset seismic survey images the transition from the shelf to unequivocal oceanic crust.

The East-Indian passive margin is the result of a complex poly-phase rifting including a transtensional component. The breakup between Antarctica and East-India occurred during Early Cretaceous time (Acharyya, 1998; Powell et al., 1988; Storey et al., 1995; Subrahmanyam and Chand, 2006). The East-Indian margin is the conjugate to the East Antartica's Enderby basin, the Princess Elizabeth Trough and the Davis Sea basin (Ramana et al., 1994, Gaina et al., 2007). The break-up and formation of first oceanic crust is preceded by the exhumation of subcontinental mantle during Early Cretaceous time (Curray et al., 1982; Pateria et al., 1992). In this study, we chose the ION IE1-1000 section that we consider one of the world champion lines, preserving characteristic features of an "upper plate" margin. The ION IE1-1000 section images the entire continental crust down to mantle depths (18s TWT). The acquisition parameters and further details about data and imaging methods are described in Nemcok et al. (2013) and Pindell and Kennan (2009). The section described in this study (Fig. 3) is depth migrated. 
(a)

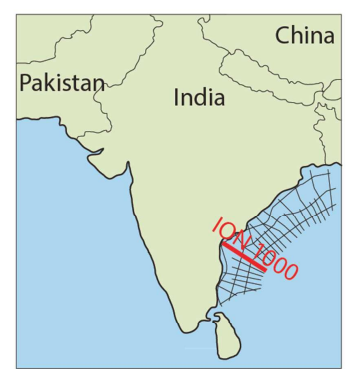

(b)

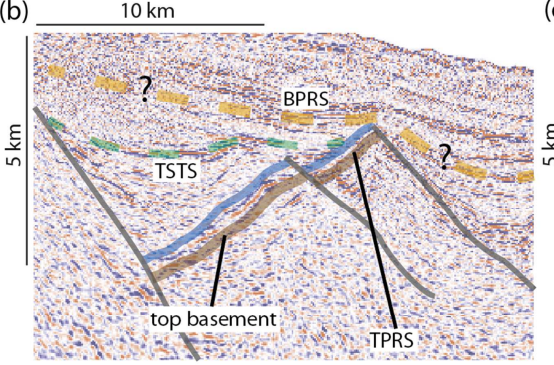

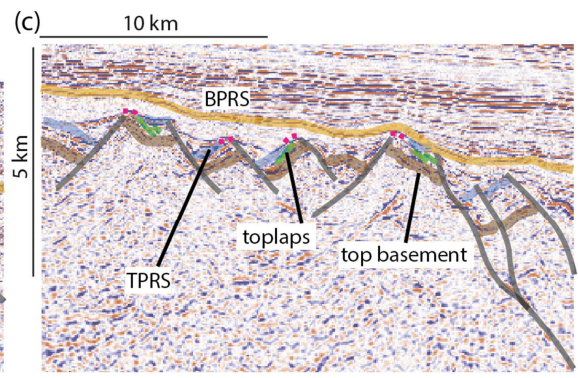

(d)

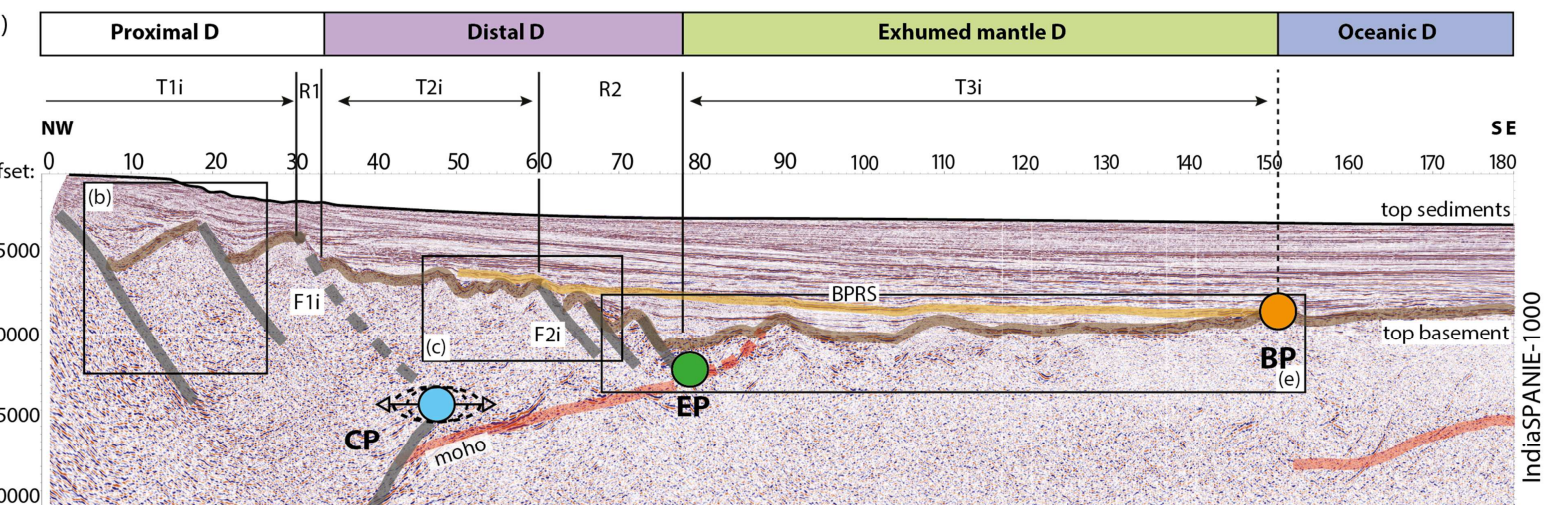

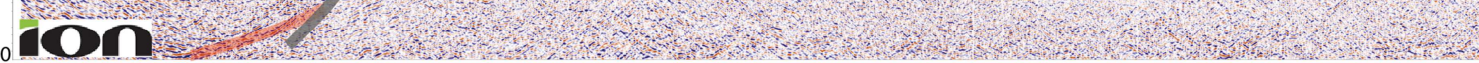

basin 1 basin 2

(e)

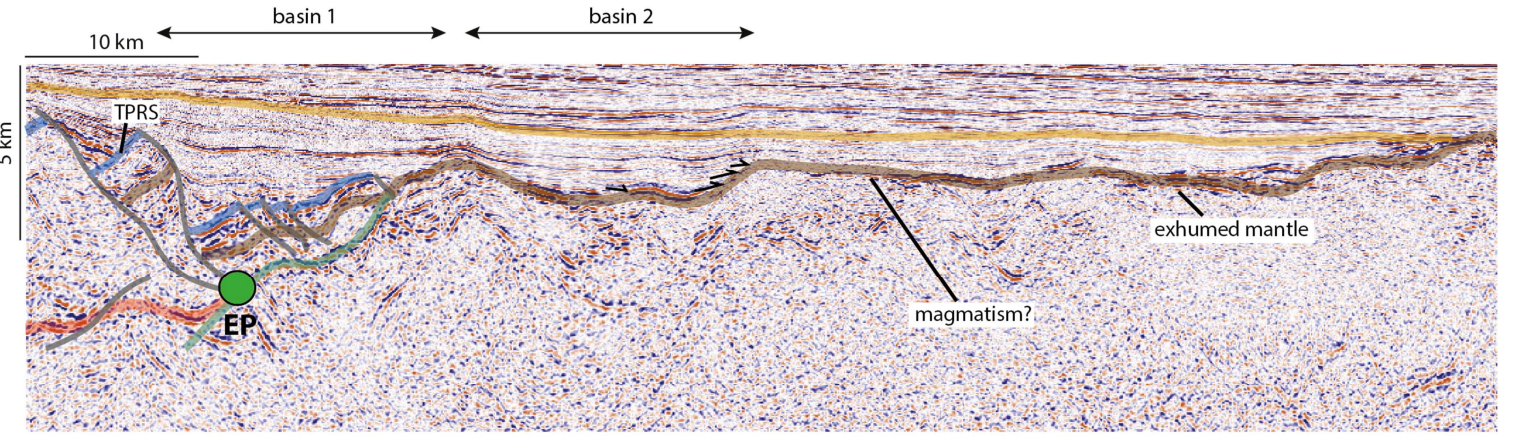

Legend

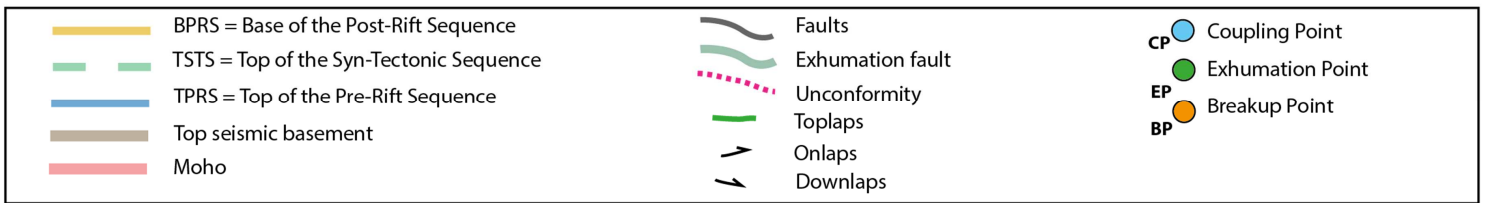

Fig.3 a) Map showing the localization of the East India ION IE1-1000 section. b) Zoom on a fault bounded basin (tilted block) located below the first terrace $\left(\mathrm{T}_{1 \mathrm{i}}\right)$. Top basement is tilted together with the TPRS along an ocean ward dipping normal fault and filled by a syn-tectonic sequence and capped by the TSTS. Location of BPRS cannot be defined. c) Zoom on the top basement of the second terrace $\left(\mathrm{T}_{2 \mathrm{i}}\right)$ and relations to overlying sediments. Note that tilted blocks are smaller, syn- and antithetic normal faults can 
be observed and erosional surfaces can be observed with locale toplaps. d) Crustal scale view of the IONIE1-1000 line showing the typical staircase top basement architecture with three terraces $\left(T_{1 i}, T_{2 i}, T_{3 i}\right)$ bounded by 2 major escarpments $\left(\mathrm{R}_{1 \mathrm{i}}\right.$ and $\left.\mathrm{R}_{2 \mathrm{i}}\right)$ that are associated with fault systems $\left(\mathrm{F}_{1 \mathrm{i}}\right.$ and $\left.\mathrm{F}_{2 \mathrm{i}}\right)$. Note also that location of $\mathrm{CP}, \mathrm{EP}$ and $\mathrm{BP}$ is closely related to the major fault systems and ramps and enables to define rift domains and domain boundaries. e) Zoom on the most distal part of the margin showing the transition from the $T_{2 i}$ to the $T_{3 i}$ which corresponds to a major escarpment $\left(\mathrm{R}_{2 \mathrm{i}}\right)$ formed by major normal faults that are truncated at the base by a strong reflection (red line in section), interpreted as the Moho that projects towards the seafloor. Oceanwards of $\left(\mathrm{R}_{2 \mathrm{i}}\right)$ there is a change in the top basement architecture from fault bounded blocks that are over-tilted and interpreted to be formed by extensional allochthons of continental crust overlying an exhumation fault and exhumed mantle. The exhumation fault corresponds to the top of the mantle. Oceanwards the top of basement shows more symmetrical built ups with passive infill that may correspond to magmatic additions. Note also that on the oceanward part the sedimentary infill down(on)lap onto basement. The BPRS is interpreted to correspond to the first sediments that are on first oceanic crust.

\subsubsection{Crustal architecture}

The ION IE1-1000 line shows marked changes in the crustal architecture from its proximal to its distal domain. These changes are best depicted by an increase of total accommodation space (sediment plus water) oceanwards, a change in the morphology of the top seismic basement and characteristic intra-basement reflections.

Top seismic basement can be observed at approximately $2 \mathrm{~km}$ below sea level at the most proximal part of the line and drops to about $10 \mathrm{~km}$ further distal. At the most oceanward part top basement is at $8.5 \mathrm{~km}$ below sea level. At its proximal part (between $\mathrm{km} 00$ and 30 in Fig. 3d) top basement is dissected by two major normal faults. These faults are not cutting across the entire 
continental crust but affect only its upper part (i.e. the brittle upper crust). Further oceanwards, between $\mathrm{km} 30$ and 60, top basement is limited by two major normal fault systems referred to as $F_{1 i}$ and $F_{2 i}$ (Fig. 3d). Between these two faults, top basement is dissected by several smaller, synthetic and antithetic faults, and the overall top basement is at about $7 \mathrm{~km}$ depth. Across both $F_{1} i$ and $F_{2 i}$ major thinning of the crust can be observed. Ocean wards of $F_{2 i}$, between $k m 66$ and 90, top basement reaches the deepest point across the section (down to $10 \mathrm{~km}$ ) and is heavily structured. While the continent ward part is formed by over tilted, crustal blocks truncated by ocean ward dipping faults, the oceanward part is smoother and controlled by symmetric build ups with passive infill and minor faults. Between $\mathrm{km} 90$ and 150 the basement rises approximately to 8km depth and becomes sub-horizontal from km 150 oceanwards (Fig 3).

Intra-basement reflectors are observed across the whole section as shown in the seismic interpretation (Fig 3d). Reflectivity in the crust is ill defined and difficult to interpret. From km 20 to 60 , a major reflector can be observed rising from more than $25 \mathrm{~km}$ depth to approximately $14 \mathrm{~km}$ depth. Since the rise of this reflector is compensated by a deepening of top basement and an increase in total accommodation space, we interpret this reflector as a Moho reflection that juxtaposes rocks of different densities. This interpretation is in line with previous interpretations by Nemcok et al. (2013) and Pindell et al. (2009). The Moho reflection is also cut, in our interpretation, by normal faults that dip continent wards, opposed to the faults observed in the upper crust (e.g. $F_{1} i$ and $F_{2 i}$ ) (Fig 3d). On the deepest part of the margin (between km 70 and 92) an upwards continuation of the Moho reflection can be observed approaching top basement. $F_{2 i}$ is truncated by the upward continuation of the Moho reflection that can be projected to cut out at top basement at $\mathrm{km} \mathrm{92.} \mathrm{In} \mathrm{our} \mathrm{interpretation,} \mathrm{the} \mathrm{mantle} \mathrm{is} \mathrm{overlain} \mathrm{by} \mathrm{continent-derived}$ allochthonous blocks. From km 92 to 150, basement may be formed by exhumed serpentinized mantle, which may explain the lack of potential Moho reflections (see Sutra et al. 2013). 
Oceanwards of $\mathrm{km} \mathrm{150,} \mathrm{a} \mathrm{weak} \mathrm{reflectivity} \mathrm{at} \mathrm{about} 6$ to $7 \mathrm{~km}$ below top basement can be observed, which is parallel to top basement and may be interpreted as base of the oceanic crust, i.e. oceanic Moho.

Based on the definition of top and base of the crust, we can define, following the approaches developed by Sutra et al. (2013) and Tugend et al. (2015) margin domains as well as the location of the CP, the EP and the BP (Fig. 3). Four domains can be distinguished: the proximal domain, the necking and hyper-thinned domains, here referred to as distal domain, the exhumed domain and the oceanic domain. In contrast to lower plate margins described by Sutra et al. (2013), the distinction between the necking and hyper-extended domains is difficult and therefore we do not separate these two domains. The location of the $\mathrm{CP}$ is difficult to define in upper plate margins due to the fact that it is masked by the residual $\mathrm{H}$ block (see H(r) in Fig. 2). In this study we define the location of $\mathrm{CP}$ as the focal point of major $\mathrm{F}_{1 \mathrm{i}}$ faults). In contrast, the EP can be well defined in the section (intersection of $\mathrm{F}_{2 \mathrm{i}}$ with the upward projection of the Moho reflection). Since the CP, as defined by Sutra (2013), describes the passage from the decoupled to the coupled domain, ductile layers are not present anymore in the crust oceanwards of the $\mathrm{CP}$, and the major faults can truncate the whole thinned continental crust (e.g. $\left.F_{2 i}\right)$. The EP meanwhile defines the boundary between the distal domain and the exhumed mantle domain and corresponds to the termination of the autochthonous Indian continental crust. Oceanwards of the EP, remnants of continental crust may occur only as allochthonous blocks overlying exhumed mantle and associated with possible magmatic additions. The BP coincides with the location where steady state seafloor spreading occurs. In the ION IE1-1000 line we define the BP as the location where top basement becomes sub-horizontal and underlain by a Moho reflection that parallels topbasement. Along the ION IE1-1000 line, the first oceanic crust is about $8.5 \mathrm{~km}$ thick, which is unusually thick comparing to the 6 to $7 \mathrm{~km}$ expected for normal oceanic crust (see Dick et al., 
2003). However, Bronner et al. (2011) showed that at magma-poor rifted margins this initial thicker crust may be related to the breakup process and may result from an excess magmatic event related to breakup.

It is important to note that each of the domains show a characteristic crustal thickness. Due to the fact that the East Indian margin is thermally equilibrated, the different crustal thicknesses also result in a characteristic accommodation space that reflects the isostatic equilibrium of each of the domains (e.g. Tugend et al., 2015). This results in a stair-type top basement geometry that can be defined by terraces $(\mathrm{T})$ and ramps $(\mathrm{R})$, which is main characteristic for an upper-plate margin. While the terraces occur over domains with similar crustal thickness, the ramps coincide with parts of the margin where abrupt crustal thickness changes occur. Across the East Indian section, three terraces placed at different bathymetric level can be defined: $T_{1 i}, T_{2 i}$ and $T_{3 i}$. The three terraces are limited by two major ramps $R_{1}$ and $R_{2}$ that coincide with the locations of fault systems $F_{1 i}$ and $F_{2 i}$. The terraces are also characterized by distinct top basement topographies. While $T_{1 \mathrm{i}}$ is defined by large-scale fault bounded basins affecting the uppermost brittle crust, $\mathrm{T}_{2 \mathrm{i}}$ shows smaller, scattered faults and occurs over brittle crust, and $\mathrm{T}_{3 \mathrm{i}}$ shows a wide and back rotated top basement topography and magmatic additions. The transition from T3i to oceanic crust is defined by the inflection point between a rising top basement (from $10 \mathrm{~km}$ to $8 \mathrm{~km}$ ) and a sub-horizontal top basement over the oceanic domain. The rise of top basement suggests either a thickening of basement or a change in density of the rocks forming the basement between the EP and the $\mathrm{BP}\left(\mathrm{T}_{3 \mathrm{i}}\right)$. The thickening is best explained by possible magmatic additions becoming more important oceanwards (Fig. 3). 


\subsubsection{Stratigraphic architecture}

The total accommodation space, including sediments and water, increases from $\mathrm{T}_{1 \mathrm{i}}$, through $T_{2 i}$ to $T_{3 i}$ and remains, on a locale scale, constant over oceanic crust. In classical interpretations, stratigraphic units are subdivided in pre-, syn- and post-rift. However, as discussed in many papers (see Masini et al., 2013 and references there in) the problem in subdividing units in pre-, syn- and post-rift is that sedimentary units showing syn-tectonic geometries are not necessary of the same age and can therefore not be correlated across the whole margin. While this problem has been discussed for lower plate margins (see Masini et al., 2012, 2013) it has not yet been discussed for upper plate margins. In this study, we will use the terms pre-, syn- and post-rift strictly as time sequences. The term syn-rift refers to the time between onset of rifting and onset of steady state seafloor spreading. The syn-rift sequence is limited at its base by the Top of the Pre-Rift Sequence (TPRS) and at its top by the Base of the Post-Rift Sequence (BPRS). While the TPRS is best expressed over $\mathrm{T}_{1 \mathrm{i}}$, where tilted sections underlie a growth sequence, the BPRS is defined as the first sedimentary sequence overlying oceanic crust at the BP. Therefore, the age of the BPRS strongly depends on the location of BP and consequently on the definition of breakup. Classically the BPRS coincides with the sequence that caps the growth sequence in the proximal margin. However, Wilson et al. (2001) and Masini et al. (2013) showed that this sequence is in many margins older than the BPRS. The correlation of the BPRS from $T_{3 i}$ across $T_{2 i}$ to $T_{1 i}$ is in many margins, in the absence of drill-hole data, difficult and depends on the tectonic model. Therefore, for the East Indian ION IE1-1000 line, the correlations of the TRPS and BPRS are not possible across the entire margin. A stratigraphic model for an upper-plate margin will be proposed and discussed in chapter 4. 


\subsection{The Newfoundland margin (SCREECH 2 line)}

\subsubsection{Data and context}

The Iberia-Newfoundland conjugate rifted margins result from a protracted rift evolution (Triassic to Late Jurassic) and final separation of the Iberia and North-America plates during Early Cretaceous. The exceptional dataset and the absence of salt in the distal parts makes this conjugate margin system one of the best-documented and studied worldwide. In particular the basement architecture, its nature, and the tectonic evolution of this system have been studied by many researchers (Hopper et al., 2004; Huismans and Beaumont, 2011; Lavier and Manatschal, 2006; Ranero et al., 2006; Shillington et al., 2006; Sutra and Manatschal, 2012). In this paper we will focus on the Newfoundland margin and more particularly on the SCREECH 2 line that we consider as another champion line across an upper-plate magma-poor rifted margin (Hopper et al., 2004; Schilligton et al., 2006; Lau et al., 2006).

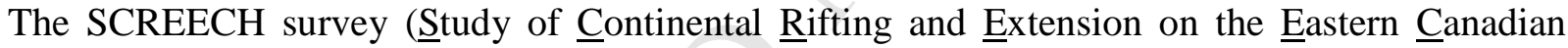
shelf) was conducted in 2000 on the eastern Grand Banks-Newfoundland basin margin. Three transects of coincident multichannel seismic and wide-angle reflection and refraction data were collected using bottom hydrophones and seismometers.

Of major importance for the interpretation of the SCREECH 2 line are the ODP drill holes that have been drilled on the most distal part of the section at the transition to first oceanic crust during ODP Leg 210 (Tucholke et al., 2004). In this context it is important to note that the SCREECH 2 line is conjugate to a drilled transect along the Iberia margin that was drilled during a DSDP Leg 48 (Deep See Drilling Project, (Sibuet and Ryan, 1979) and ODP Legs 149 and 173 (Beslier et al., 1994; Whitmarsh and Sawyer, 1996; Minshull et al., 1998). These drill holes provide important information about the tectono-stratigraphic evolution of the conjugate lower plate margin (Péron-Pinvidic et al., 2007). 


\subsubsection{Crustal architecture}

The SCREECH 2 line shows, similarly to the East Indian ION- 1000 section, a stair-type top basement geometry and an increase in total accommodation space oceanwards (Fig. 4c). This enables us to describe the SCREECH 2 line using the same approach and terminology. It is, however, important to note that the SCREECH 2 line is less well imaged, its most continent ward part is missing and the line is in two way travel time.
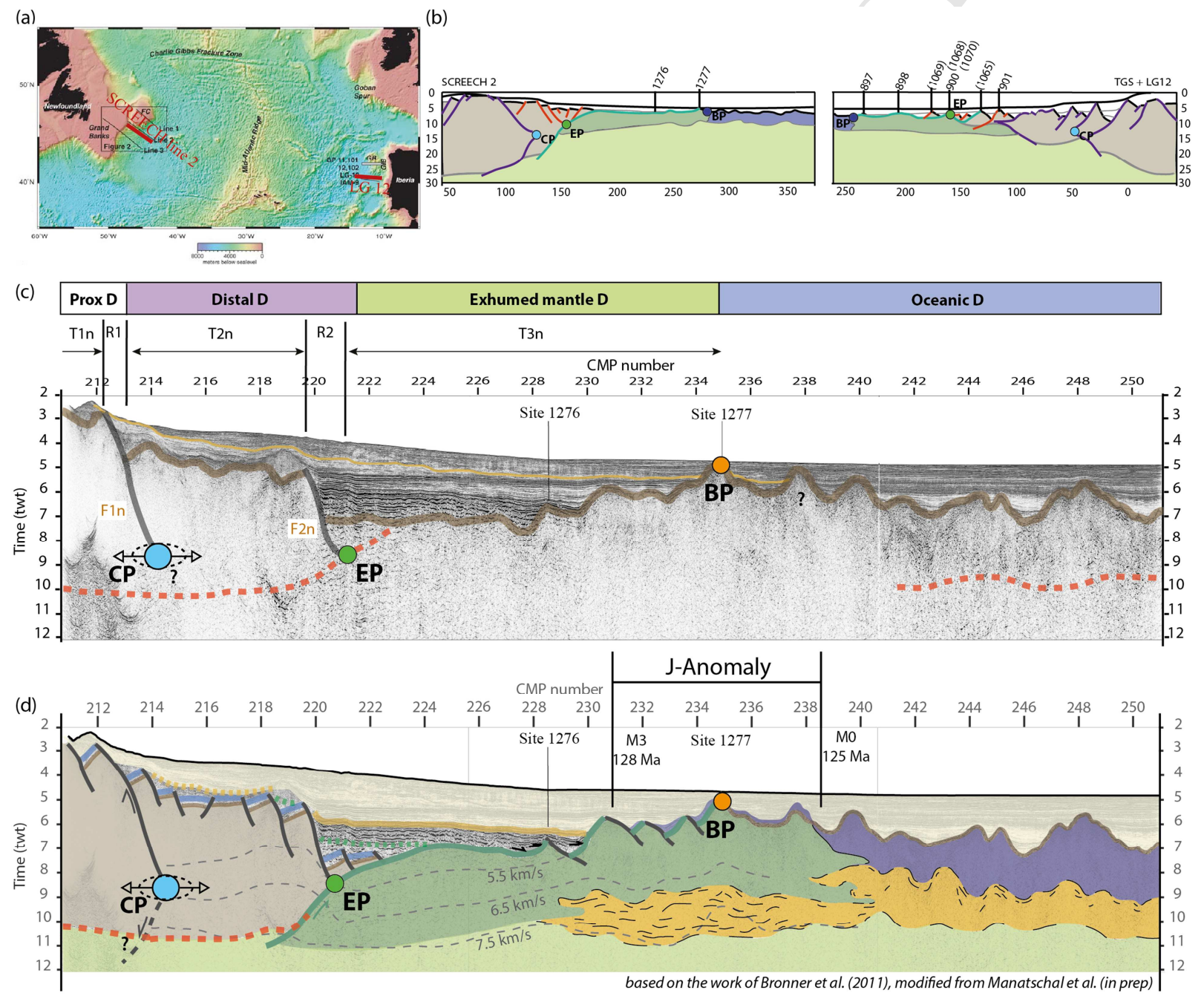

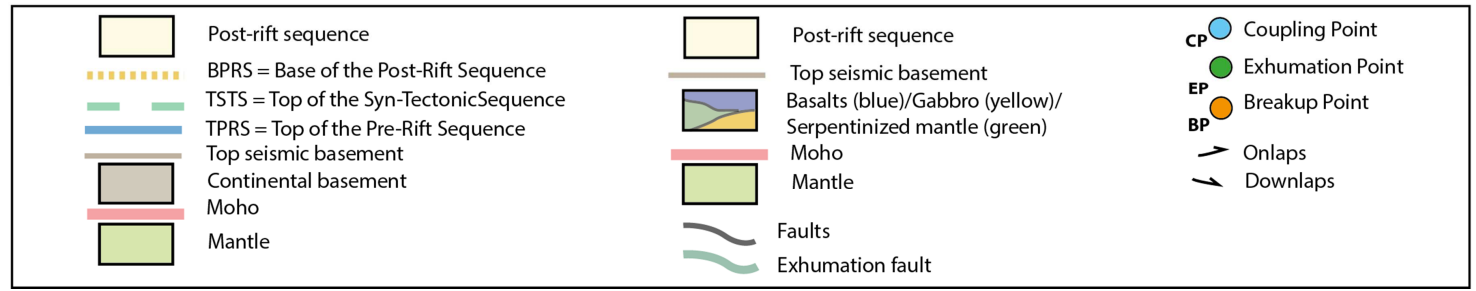


Fig.4 a) Reconstruction of the Newfoundland-Iberia rift system at anomaly M0 (from Bronner et al. 2011). b) Interpreted section across the Iberia-Newfoundland rifted margin showing SCREECH 2 section and the conjugate TGS/LG12 sections and the location of the ODP Sites (where ODP Site numbers are in brackets the sites are projected into the line) (modified from Sutra et al. 2013). c) Seismic section SCREECH 2 with interpretation of top basement, Moho, major fault systems $F_{1 n}$ and $F_{2 n}$ and the BPRS and the locations of the CP, EP and BP (for more details and explanations of the locations of the latter as well as the interpretation of the rift domains and domain boundaries see text). d) Interpretation of SCREECH 2 section integrating the velocity from van Avendonck et al (2006) and the drill hole data.

The top basement is not well imaged on the continent ward side and as a consequence, the detailed structure is difficult to describe. However it can be seen that top basement is dissected by two major fault systems $\left(F_{1 n}\right.$ and $\left.F_{2 n}\right)$ that define two ramps $\left(R_{1}\right.$ and $\left.R_{2}\right)$ separating three terraces $\left(\mathrm{T}_{1 \mathrm{n}}, \mathrm{T}_{2 \mathrm{n}}\right.$ and $\mathrm{T}_{3 \mathrm{n}}$ ) (Fig. $4 \mathrm{c}$ ). Details of the top basement are difficult to define on the continental side, although it can be seen that the total accommodation space increases abruptly across the ramps. Oceanwards of CMP number 226 top basement is well imaged. From CMP number 226 to 235 the latter coinciding with ODP Site 1277, top basement rises from 7.5 to $4.8 \mathrm{sec}$. The top basement is dissected by low-angle faults and an over-rotated top-basement that carries continentwards tilted sections. Ocean ward of ODP Site 1277 top basement is formed by basement highs up to $4 \mathrm{~km}$ wide and $1.5 \mathrm{sec}$ vertical topography lying at a medium depth of 6.5 sec.

Intra-basement reflections are ill defined, apart from a strong reflection that is at about $10 \mathrm{sec}$ depths at CMP number 218 underlying the ocean ward part of $\mathrm{T}_{2 \mathrm{n}}$. Refraction seismic data show that the reflection corresponds to a Moho reflection and the velocity structure enables to define top seismic basement at about $4.5 \mathrm{sec}$ (Van Avendonk et al., 2006). Oceanward of CMP number 
218, sediment reflections can be seen dropping down to more than $7 \mathrm{sec}$, however, top basement is not well imaged on the section. Oceanwards, reflectivity in the seismic basement is sparse and does not show clear intra-basement or Moho reflections. Velocity contours are shown in Fig. $4 \mathrm{~d}$ that are taken from Van Avendonk et al. 2006 (see also Bronner et al. 2011). As expected, velocity of $8 \mathrm{~km} / \mathrm{sec}$ (top of unserpentinized mantle) is at about $11 \mathrm{sec}$. While reflection seismic data is unable to resolve the precise structure of the crust, the refraction seismic data enables to define unthinned, necked and hyper-extended crust and the occurrence of exhumed serpentinized mantle (Van Avendonk et al. 2006). The first order architecture shown by the refraction seismic data confirms the stair-type geometry of top basement with $T_{1 n}, T_{2 n}$ and $T_{3 n}, R_{1 n}$ and $R_{2 n}$ (these latter corresponding to the location of $F_{1 n}$ and $F_{2 n}$ ). The location of the $\mathrm{CP}$ is difficult to define. In Fig. 4 it has been located in the prolongation of $F_{1 n}$ at about $4 \mathrm{sec}$ below top basement (about 10 to 15 $\mathrm{km}$, corresponding to the assumed brittle ductile transition assuming a quartzo-feldspathic crust and a normal geothermal gradient of $30^{\circ} \mathrm{C} / \mathrm{km}$ ). The EP is located at CMP number 221 and corresponds to the intersection of $\mathrm{F}_{2 \mathrm{n}}$ with the projection of the Moho-reflection towards the seafloor. The BP has been set at CMP number 235, corresponding to ODP Site 1277. Indeed, the transition between $T_{3 n}$ and the first oceanic crust corresponds to a basement high that is located between CMP number 230 and 238. During ODP Leg 210, 2 drill holes penetrated the complete stratigraphic section down to the top Aptian (ODP Site 1276 at CMP number 228.5 and top basement at ODP Site 1277 at CMP number 235). The basement at ODP Site 1277 is made of serpentinized mantle rocks intruded and overlain by igneous rocks. Dating of the igneous rocks, by $\mathrm{U}-\mathrm{Pb}$ and ${ }^{39} \mathrm{Ar}-{ }^{40} \mathrm{Ar}$ measurements, suggest an emplaced age of these rocks between $126 \mathrm{Ma}$ and $113 \mathrm{Ma}$ (Jagoutz et al. 2007). The older ages indicate that the basement underlying the high had to be accreted at least at $126 \mathrm{Ma}$, which is compatible with the occurrence of Aptian sediments over this basement and other basement highs across the conjugate Iberia- 
Newfoundland margins (Péron-Pinvidic et al. 2007). The younger ages suggest that this high had a protracted magmatic history, which is well described and further supported by the occurrence of sills drilled at ODP Site 1276 (Péron-Pinvidic and Manatschal, 2010). Refraction seismic data show that the $8 \mathrm{~km} / \mathrm{sec}$ contour, which defines geophysical Moho, is at about $3 \mathrm{sec}$ (about $9 \mathrm{~km}$, assuming average velocities of $6 \mathrm{~km} / \mathrm{s}$ ) below top basement drilled at ODP Site 1277. Since the crust below this site is too thick to be explained only by serpentinization, Bronner et al. (2011) proposed that the exhumed mantle was underplated by gabbro bodies. This hypothesis was further supported by the occurrence of the J-magnetic anomaly. Bronner et al. (2011) were able to model this anomaly successfully as a magnetic anomaly related to an excess magmatic event triggering lithospheric breakup. These authors proposed that the excess magmatic event occurred simultaneous and was responsible for the uplift of the basement high, which is documented by the occurrence of tectono-sedimentary and sedimentary breccias reworking the underlying basement, interleaved with mafic flows at ODP Site 1277 (Robertson, 2007). These breccias are in the same position as those drilled over basement highs floored by serpentinized mantle at the conjugate Iberia margin (ODP Sites 897 and 898, 1968 and 1070), altogether dated as Aptian. The fact that the Late Aptian was drilled at ODP Site 1276 and can be observed to be continentward tilted on the western flank of the high drilled at ODP Site 1277, suggests that the high was formed after deposition of the Aptian sediments, but before the deposition of the Albian sediments that represent the first sedimentary sequence filling passively the exhumed mantle domain along the Iberia-Newfoundland margins. Based on these observations the breakup is suggested to coincide with an excess magmatic event that resulted in a thickening of the previously exhumed mantle, the formation of a basement high and is recorded by a magnetic anomaly (J). These observations, so far the only made at such a distal part of the margin, have important implications for the location and age of breakup and the geometrical relationships 
between sediments and fault structures. Therefore they will be used in the stratigraphic interpretation.

\subsubsection{Stratigraphic architecture}

As discussed by Wilson et al. (2001), Tucholke and Sibuet (2007), Péron-Pinvidic et al. (2007) and Alves et al. (2009) the stratigraphic architecture of the Iberia-Newfoundland margins is complex and polyphase. In this section, we will try to first define the TPRS and BPRS horizons. The age of the TPRS is difficult to define, since the rift in the southern North Atlantic was polyphase and different TPRS can be defined corresponding to different rift events. Thus, over the whole area the TPRS does not necessarily correspond to one horizon and it can therefore not be considered as a time marker. It may correspond to either Triassic or Jurassic depending on the location and/or the definition of the TRPS. Thus, it can be labeled as TRPS ${ }_{\mathrm{T}}$ or $\mathrm{TRPS}_{\mathrm{J}}$ or, when not further defined as TRPS $_{\mathrm{T} \& \mathrm{~J}}$.

The age of the BPRS corresponds to the Aptian-Albian (Tucholke and Sibuet, 2007, PéronPinvidic et al. 2007). It is important to note, that the BPRS, also referred in the literature as the "U" reflection along the Newfoundland margin (see Tucholke et al. 2007), has been drilled along the Iberia-Newfoundland margin. In addition the BPRS does not correspond to the base of the passive infill across the whole margin. Indeed, as previously reported by Péron-Pinvidic et al. (2007) (see also their Fig. 11), the BPRS corresponds only at the most distal, exhumation domain where breakup occurred, to the base of the passive infill (see observations reported from ODP Site 1277 above). Further continentward, the BPRS overlies sediments that are pre-BRPS but still show a passive infill that we refer to as "sag"-sequence (for a definition of a sag sequence see Masini et al. 2013). 
A key stratigraphic horizon that can be defined across the Iberia-Newfoundland sections shown at Fig. 4 is the top Jurassic (Tithonian). This stratigraphic horizon has not been drilled along the Newfoundland margin, but along the Iberia Abyssal Plain, where it has been recovered at ODP Sites 901, 1065, 1069 (Mohn et al., 2015). This horizon changes oceanwards and from south to north from syn-tectonic in the proximal margin and in the south to pre-tectonic across the $\mathrm{CP}$ and moving northwards (Sutra et al. 2013; Mohn et al. 2015). At ODP Sites 901, 1065 and 1069 the Tithonian had been drilled and it is clearly truncated by the major exhumation fault. Thus, the Tithonian changes from syn- to pre-tectonic across the necking zone, suggesting that necking occurred during Tithonian time between SCREECH 2 and the conjugate TGS-LG12 lines (Fig. 4b). This observation indicates that time correlations across the margin, and more particularly across the distal margin are problematic and cannot be described by using the classical pre-, synand post-rift terminology.

\subsection{The European margin}

\subsubsection{Data and context}

In contrast to the previous two examples, where the crustal structure can be imaged by seismic methods, in the example of the European margin (Fig. 5) the crustal rift architecture had been destroyed during Alpine reactivation. Nevertheless, isolated fragments of the former margin survived within the Alpine nappe stack preserving primary, rift-related stratigraphic contacts and rift structures (Lemoine et al., 1986 and for a more recent reviewed see Mohn et al., 2010). The paleogeographic reconstruction of the remnants of the European margin has been done by defining their position in the nappe stack and/or the stratigraphic content. This concept did not significantly change since the early days of Alpine geology (Argand, 1911, 1916, 1920). The 
restorations resulted in debates about the existence or non-existence of a Cretaceous Valais basin (Stampfli et al., 1991; Trümpy, 1980), as well as the lateral correlation of some rift domains, in particular of the Briançonnais domain (Fig.5a, 5d). Nevertheless, there is a general consensus about the first order distribution of the paleogeographic rift domains of the former European margin within the Alps (Lemoine et al. 1986), which are from proximal to distal the Provence/Dauphinois/Helvetic domain, the Briançonnais s.l. domain, and the exhumed and protooceanic Prepiemontais and Piemonte Ligurian domains (Fig.5a). Moreover, since the work of Lemoine et al. (1987) it is generally accepted that the European margin corresponds to an upperplate margin (for more details see also Manatschal (2004)). 
(a)

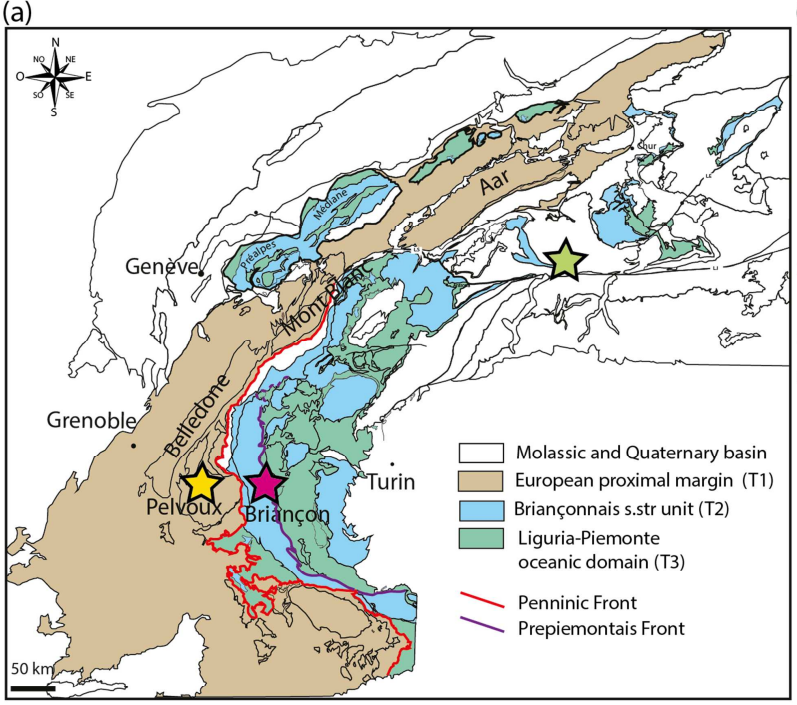

(b)

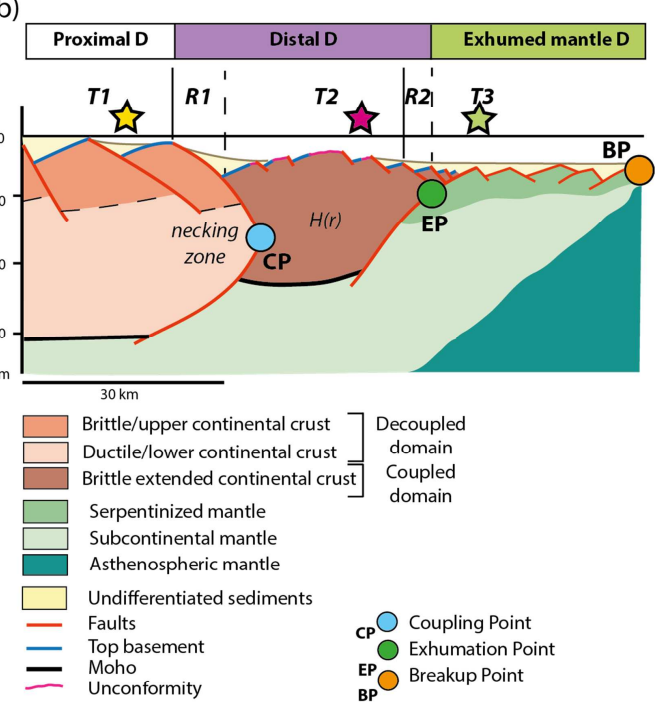

(c)
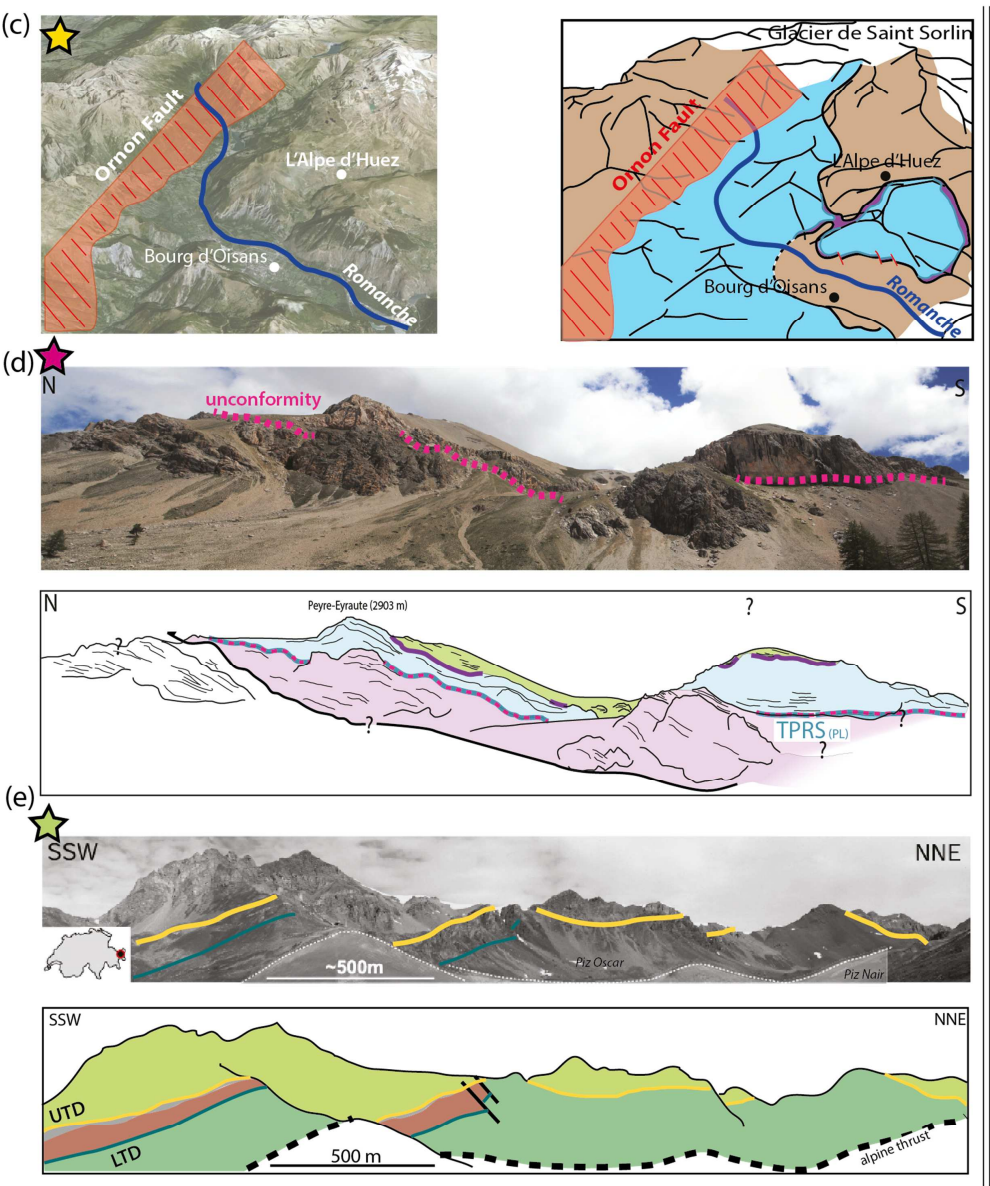

W Bourg d'Oisans ? E

_ _ , Bourg d'Oisans ? _BPRS
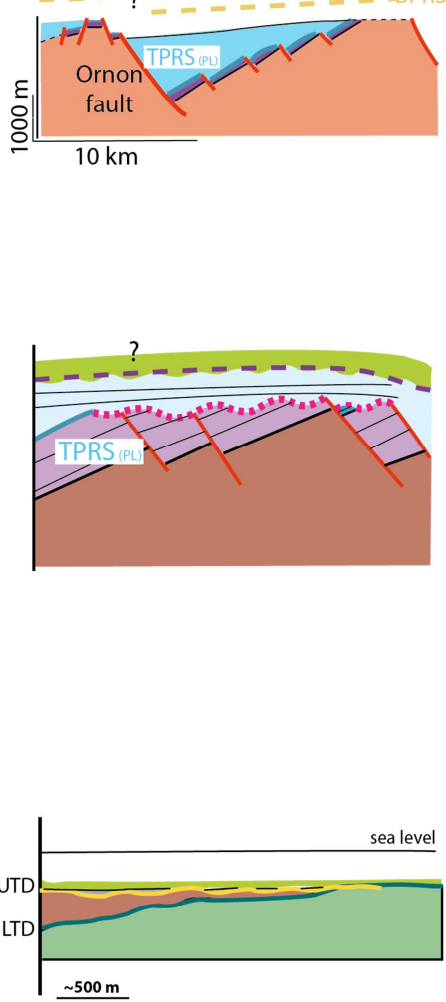

\begin{tabular}{|c|c|c|c|}
\hline$\square$ Upper Cretaceous & $\square$ crystalline breccia & $\sim$ Alpine thrust & — UTD Upper Tasna Detachment \\
\hline$\square$ Upper Jurassic & continental crust & - TPRS (PL) & LTD Lower Tasna Dectahment \\
\hline Lower Jurassic & serpentinized mantle & 2nd unconformity & \\
\hline$\square$ Upper Triassic & & Wul 1st unconformity & \\
\hline
\end{tabular}


Fig.5 a) Map of the Alps showing the principal paleogeographic domains of the European margin. The stars show the location of the 3 sites where rift structures discussed in the paper are exposed. b) Schematic section across an upper plate of a magma-poor rifted margin with projected location of the discussed Alpine sites. c) Google Earth view of Bourg d'Oisans in the former proximal European margin preserving a fault bounded basin (modified from Chevalier et al., 2012). d) Panoramic view of the Peyre Eyraute summit south of Briançon in the former distal European margin showing the major Briançonnais unconformity. e) Panoramic view of the Tasna OCT in the Lower Engadine valley (SE Switzerland) preserving the most distal margin and exhumed mantle domain of the European margin. For a more detailed description of the outcrop observations see text.

In this section, we will neither focus on the details of possible restorations of the former European margin, nor on the description of the detailed crustal structure that remains hypothetical and depends on the restoration of the Alpine nappe stack. The aim of this paragraph is to focus to three km-scale outcrops that represent the characteristic tectono-stratigraphic relationships of each of the 3 main paleogeographic domains forming the fossil European margin.

\subsubsection{Outcrops preserving the structure and stratigraphic architecture of the former margin}

\section{Bourg d'Oisans: fault bounded basin in the proximal domain}

The Bourg d'Oisans area (Fig.5c) preserves a series of fault-bounded basins that structure the proximal European margin and that are relatively little affected by Alpine deformation (Montadert et al. 1979; Lemoine et al., 1986; Bellahsen et al., 2012; De Graciansky et al., 1979; Dumont et al., 2008). These basins are preserved within the external crystalline massifs (Belledonne, Grandes Rousses and Pelvoux), which are composed of Palaeozoic basement separated by a regional unconformity from its Upper Carboniferous to Mesozoic sedimentary 
cover (Chevalier et al., 2003; Dumont et al., 2011). The TPRS within these basins corresponds to the top of a thin sequence of Middle to Upper Triassic dolostones and evaporites (Fig.5c). The Lower Jurassic limestones and marls overlying the TPRS mark the deepening of the depositional environment within a fault-bounded basin as evidenced by angular unconformities and sharp facies changes (Barféty and Gidon, 1984; Chevalier et al., 2003; Gillcrist et al., 1987; Lemoine et al., 1986). Rifting within this domain stopped at Sinemurian to Pliensbachian time (see Chevalier et al. 2002), which is about 20 Ma before the BPRS (Radiolarian cherts dated as Bathonian to Callovian in the European margin (Bill et al., 2001)). The BPRS is not preserved directly in the Bourg d'Oisans area due to erosion, however, the post-rift stratigraphic section within the proximal European margin is formed by an Upper Jurassic-Lower Cretaceous pelagic to hemipelagic succession composed of limestones and marls followed by a thick succession of platform carbonates of Cretaceous age. The occurrence of these latter shows that this domain remained at relatively shallow-water depth during and also after rifting indicating that the underlying crust was not significantly thinned during Jurassic rifting. This is also supported by the observation that these basins are overlying present-day normal thickness crust (e.g. ECORSCrop section; Group et al., 1989) and lie in an external part of the Alps that was not heavily thickened during Alpine convergence.

\section{Fond Froid - Lac de l'Ascension : major rift unconformity}

Fond Froid (Fig. 5d) and Lac de l'Ascension belong to the Briançonnais domain. They are part of a thrust-stack, including the Champcella and Peyre-Haute units (Claudel, 1999). The Briançonnais units consist of a discontinuous Carboniferous-to-Eocene sedimentary succession, with important unconformities and hiatuses. The Permo - Triassic sequence is locally very thick and includes a basal siliciclastic succession, which displays a rough fining-upward arrangement 
that is followed by quartzites, pelites and thick Middle-to-Upper Triassic carbonate platform successions interleaved by Carnian evaporites. The occurrence of such a thick sedimentary succession leads to the question about the age of onset of rifting, which is, across the Alpine margin, diachronous (Tricart et al., 2007). Indeed, the definition of the TPRS is difficult due to the poly-phase and protracted rift evolution of the Alpine domain, including a Triassic rift system located in the east (Meliata system) that was overprinted at its western side by a Jurassic rift system (Piemonte-Ligurian system; $c f r$. Decarlis et al. 2015). In this study we define a TPRS(ML) and a TPRS( ${ }_{\mathrm{PL}}$ ) related to Triassic rifting in the Meliata and Early to Middle Jurassic rifting in the Piemonte-Liguria domains. While the $\operatorname{TPRS}\left({ }_{\mathrm{ML}}\right)$ is at the base of the thick Mid Triassic dolomites and yet little understood, the TPRS( $\left.{ }_{\mathrm{PL}}\right)$ is at the top of the Triassic carbonates and commonly referred to as the onset of rifting (Fig.5d). Although we do not go into further detail, it is important to note that such type of complexity may be more common at rifted margins (e.g. Iberia margin). As a consequence the stratigraphic record of rift systems can be highly complex due to the polyphase nature of rifting.

The most prominent feature in the Briançonnais is a major unconformity/hiatus, which is commonly interpreted to be related to a major uplift and erosion/karstification of the Triassic carbonate platform during Early Jurassic (Schneegans, 1933; Barféty et al., 1970, 1972; Baud and Megard-Galli, 1975; Baud, 1976; Claudel and Dumont, 1999). From Bajocian/Bathonian onwards, a generalized transgression onto the Briançonnais domain led to the deposition of neritic limestones (Barfety, 1965; Bourbon, 1980, 1977; BOURBON, 1972; Bourbon, 1971) that correspond to the BPRS (Fig. 5d). The late-Middle to Upper Jurassic sedimentary record, belonging to the post-rift sequence, is characterized by pelagic clayey limestones overlain by Upper Jurassic limestones with nodular Ammonitico Rosso facies. The occurrence of Upper Cretaceous limestones directly on top of the Jurassic Ammonitico Rosso, indicates a major 
sedimentary hiatus of Lower Cretaceous age, often marked by a hardground (Barfety, 1965; Bourbon, 1971, 1972, 1977, 1980). Upper Cretaceous to lower Eocene sediments are mainly of pelagic origin ("marbres en plaquette"; Termier, 1903) indicating deeper water and/or a sediment starved environment. However, the precise paleo-water depth cannot be determined with confidence.

The "unconformity" observed in the Briançonnais units, that can be found throughout the Alps, is a key to understand the margin evolution and to propose correlations between the proximal and distal parts of the margin. As shown in Fig. 5d, across the Briançonnais units, the TPRS(PL) is locally eroded and capped by the BPRS. The syn-tectonic sequence is only locally preserved. These relationships are either the result of condensation and/or non-deposition or deposition and erosion. It is important to note that the unconformity is not observed in the adjacent proximal or more distal domains. In detail, the observed unconformity includes two parts. An erosional unconformity at the top of the Triassic to Lower Jurassic carbonates, usually referred to as the "Briançonnais gap" (Ellenberger, 1952; Debelmas, 1955, 1987; Barbier et al., 1963; Vanossi, 1965; Baud and Masson, 1975; Baud et al. 1979; Jaillard, 1985; Lemoine et al., 1986; Faure and Mégard-Galli, 1988; Masson et al., 1980). This unconformity is often accompanied by a prominent karstification that reaches locally $300 \mathrm{~m}$ deep into the underlying Triassic carbonates (Baud and Megard-Galli, 1975). This unconformity has been classically interpreted to be related to a prolonged subaerial exposure of the platform. The oldest sediment found on top of the unconformity is a Bathonian transgressive conglomerate (Claudel and Dumont, 1999; Debelmas, 1983), which dates the first drowning. Since the Mid Jurassic Bathonian sediments are overlain by Upper Jurassic pelagic limestones, that drape the whole Briançonnais domain, a second main unconformity exists that is early Late Jurassic and that has been related to a submarine condensation. The Upper Cretaceous clayey limestones ("Calcschistes planctoniques"; cfr. 
"Marbres chloriteux"; Ellenberger, 1958) lie locally directly on top of the Upper Jurassic pelagic carbonates separated by a para-conformity or locally by a thin hardground (siliceous-phosphatic; Bourbon, 1980). The Lower Cretaceous succession is often not present in the Briançonnais domain, with local exceptions represented by the thin Upper Berriasian Calpionella limestone levels and the scattery-outcropping Aptian-Albian limestones cited by Bourbon (1980). Claudel and Dumont (1999) interpreted this unconformity as the result of a prominent post-rift tectonic phase that affected the margin since Callovian-Oxfordian time. An alternative interpretation is that the deposition of Upper Jurassic pelagic limestones and the lack of Lower Cretaceous sediments is the result of starvation and passive infill (see discussion below).

\section{Tasna Ocean Continent Transition (OCT): exhumation and sealing by post-rift sequence}

The Tasna OCT is exposed in southeastern Switzerland and has been described as belonging to the most distal European margin (Florineth and Froitzheim, 1994; Froitzheim and Rubatto, 1998; Manatschal et al., 2006). It is one of the rare examples where an extensional detachment fault is exposed and can be observed on a kilometer-scale without a major Alpine tectonic overprint. The first order structure shows a wedge of continental crust that is bounded at its base and top by extensional detachment faults showing the same kinematics and referred to as the Upper Tasna Detachment (UTD) and the Lower Tasna Detachment (LTD) (Fig. 5e). While the LTD separates the continental crust from the serpentinized mantle, the UTD forms the top of the basement that is continental in the south and serpentinized mantle in the north. The most important observation is that both the continental basement and the serpentinized mantle are strongly deformed along their top, being overlain locally by tectono-sedimentary breccias and sealed by shales (Tonschiefer Formation; Florineth and Froitzheim, 1994). These sediments unconformably overlie the whole Tasna OCT and are in turn overlain by grey shales, 
calciturbidites and breccias forming the Tristel Formation dated as Late Barremian to Early Aptian (Waibel and Frisch, 1989; Schwizer, 1983)). The youngest sediments in the Tasna OCT are Aptian to Eocene siliciclastic sandstones and marly limestone containing mega-breccias (for a more detailed description see Gürler, 1995 and Bertle, 2004). These sediments belong to the postrift sequence.

The key observation that can be made at the Tasna OCT is that top basement is formed by an exhumation fault that is sealed by post-rift sediments. Syn-tectonic sediments only occur locally between the exhumed basement and the post-tectonic sediments as polymictic breccias that rework and overlie the exhumed basement. They are composed of angular and rounded clasts derived from the underlying basement, indicating that they were formed during or after exhumation. Since along the Tasna OCT, mantle is exhumed at the seafloor, this outcrop belongs, with no doubt, to the deepest part of the margin. Based on the hiatus in the sedimentary sequence, Manatschal et al. (2006) proposed that the Tasna OCT may have formed a basement high that didn't retain sediments. This can explain the hiatus between syn-tectonic breccias and post-rift sediments, and point to a strong basement topography and starvation of the sedimentary system along the most distal European margin.

\section{From outcrops to the margin architecture}

While present-day margins preserve the rift architecture that can be imaged on seismic sections, outcrops within orogens can provide direct access to remnants of former rifted margins. However, despite of the high-resolution at the outcrop, the observations are often disassociated from the original context and difficult to integrate in a larger crustal scale picture of the former margin. If we use the East Indian ION IE1-1000 and Newfoundland SCREECH2 lines as a structural template for the former European margin, the Bourg d'Oisans (proximal European 
margin) would be placed in $T_{1}$, the Fond Froid - Lac de l'Ascension (Briançonnais domain) in $T_{2}$ and the Tasna OCT (Prepiemontais domain) in $T_{3}$. By adapting this analogy, $R_{1} / F_{1}$ may represent the transition between the Dauphinois and Briançonnais domain corresponding to a protoPenninic Front $(\mathrm{PF})$ and the $\mathrm{R}_{2} / \mathrm{F}_{2}$ to a proto Prepiemonte Front (PPF) in the Western Alps transect (Fig. 5). We are aware that the margin architecture has important along-strike variations and that in particular the domains between $\mathrm{T}_{1}$ and $\mathrm{T}_{2}$ evolved along strike to a basin separating these two domains (e.g. Valais basin; Trümpy (1980). However, as already proposed by Trümpy et al. (1980), we believe that the paleogeographic domains can be correlated, using first order structural and stratigraphic criteria, at least between the Western and Central Alps. The locations of the CP and the EP cannot be defined anymore in the Alpine section; however, they are likely to occur along the $\mathrm{R}_{1} / \mathrm{F}_{1}$ (proto-Penninic Front) and $\mathrm{R}_{2} / \mathrm{F}_{2}$ (proto Prepiemonte Front)

In contrast to present-day margins, where the TPRS and the BPRS correspond to reflections in seismic lines, in the Alps their definition and in particular their correlation is mainly based on age data and/or lithostratigraphic considerations. In the Alpine Tethys domain, like in the case of the Iberia-Newfoundland, the TPRS is difficult to define. Although commonly the top Triassic has been considered as the TPRS (Masini et al., 2013; Decarlis et al. 2015), the thick Triassic succession observed in the distal margin and on the conjugate Adriatic margin suggests that rifting was polyphase and can be subdivided in two events (for discussions see Decarlis et al. 2015). Therefore, two TPRS can be defined, one related to a Triassic event $\left(\mathrm{TPRS}_{\mathrm{T}}\right)$ and the other related to the Jurassic event $\left(\mathrm{TPRS}_{\mathrm{J}}\right)$. In contrast, the BPRS is well considered in the Alps and corresponds to the Radiolarian Cherts dated as late Middle Jurassic (Callovian/Bathonian). The more complex distribution of the syn-tectonic sequences across the margin will be discussed below. 


\section{Discussion}

\subsection{Crustal and stratigraphic architecture of an upper-plate magma-poor rifted margin}

Based on the description of two crustal sections and three km-scale outcrops we propose a template for the crustal architecture and discuss the structural and stratigraphic relationships and evolution of upper-plate, magma-poor rifted margins (see Fig.6). Although we are aware that margins are in reality 3D, here we integrate our observations in a $2 \mathrm{D}$ dip section.

(a)

(b)

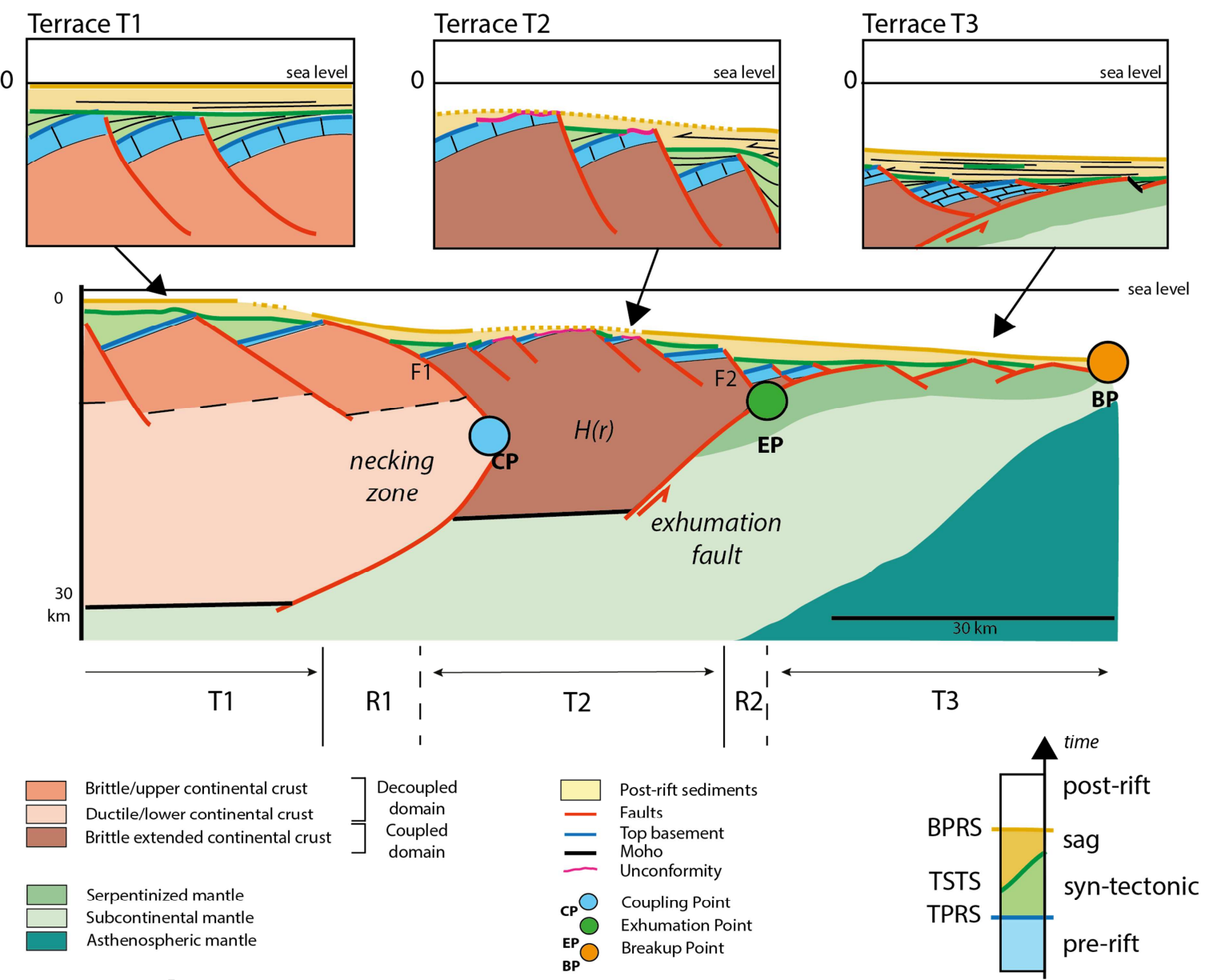

Fig.6 Schematic section across an upper plate magma-poor rifted margin with zooms (a), (b), (c) on the stratigraphic architecture of each of the three terraces $\left(T_{1}, T_{2}\right.$ and $\left.T_{3}\right)$. 
The first order characteristic of an upper plate, magma-poor rifted margin is the stair-type top basement geometry that enables to define three terraces $\left(T_{1}, T_{2}\right.$ and $\left.T_{3}\right)$. Each of these terraces is characterized by a different top-basement morphology and crustal architecture. The terraces are limited by major ramps $\left(\mathrm{R}_{1}\right.$ and $\left.\mathrm{R}_{2}\right)$ coinciding with major fault systems $\left(\mathrm{F}_{1}\right.$ and $\left.\mathrm{F}_{2}\right)$. These faults are responsible for the changes in the crustal thickness from about $30 \pm 5 \mathrm{~km}$ beneath $\mathrm{T}_{1}$ to $10 \pm 2.5 \mathrm{~km}$ beneath $\mathrm{T}_{2}$ to $1.5 \mathrm{~km} \pm 1.5 \mathrm{~km}$ beneath $\mathrm{T}_{3}$ (Fig.6), leading to the juxtaposition of domains of different thickness and/or density. As shown for the ION IE1-1000 line, these changes in crustal thickness are also associated with a change in the mode of extension from decoupled, to coupled, to exhumed and finally to seafloor spreading. The limits of these domains coincide with the $\mathrm{CP}$, the EP and the BP. It is important to note that there is a direct relationship between the location of the CP and the EP and the ramps $\left(\mathrm{R}_{1}\right.$ and $\left.\mathrm{R}_{2}\right)$ and fault systems $\mathrm{F}_{1}$ and $\mathrm{F}_{2}$ defining the limits of the terraces. This is due to the fact that there is a link between the bulk rheological evolution of the extending crust, the mode of extension, the thickness of the crust and consequently the isostatic level at which the different domains equilibrate. Linking top-basement morphology, style of deformation with total accommodation space, enables to characterize, using different observational criteria, rift domains across an upper plate margin.

For this study the most interesting part of the margin is the one between the $\mathrm{CP}$ and the EP, referred to as residual H-block (Péron-Pinvidic and Manatschal, 2010), corresponding to the $\mathrm{T}_{2}$ level and its transition towards the $\mathrm{T}_{3}$ level. These parts of the margin are diagnostic and enable to distinguish between an upper plate and a lower plate margin. The residual H-block is limited on its continentward side by the $\mathrm{R}_{1}\left(\mathrm{~F}_{1}\right)$, which coincides with the necking of the crust. Ocean wards, it is limited by the $\mathrm{R}_{2}\left(\mathrm{~F}_{2}\right)$. In the ION IE1-1000 and SCREECH 2 sections, this transition is defined by a sharp, fault controlled termination of the block with off-lapping sequences that 
inter-finger with aggradational sequences in the exhumed domain $\left(\mathrm{T}_{3}\right)$. In the example of the Alps, the residual $\mathrm{H}$ block may correspond to the Briançonnais domain exposed in the Western Alps. This domain shows a complex architecture that is strongly variable along strike (see Fig.3 and discussion in Mohn et al., 2014), including a high (Briançonnais s.str.) that is bounded continent and oceanwards by lows, in the literature referred to as the sub- and ultra-Briançonnais domains (Lefèvre and Michard, 1976). In particular the ultra-Briançonnais domain is strongly controlled by fault systems (e.g. $F_{2}$ ) and is characterized by the occurrence of gravitational sedimentary systems that are inter-fingered with basinal sedimentary sequences (Lemoine, 1961, 1967, 1960). While in seismic sections the top of the block is defined by a major unconformity, that is, however, difficult to interpret without drill hole data, in the example of the Briançonnais the stratigraphic relationships are well exposed and have been described in the previous section. The key observation is that the unconformity (Fig.6) is formed by an erosional unconformity, associated with a karst, indicating either uplift due to tectonic activity or a global sea level drop. Since the proximal margins do not show any evidence for an unconformity, we exclude the sea level drop. The hiatus may, in contrast, be interpreted by a passive infill of an existing basement high, which is also compatible with the observed hiatus in the Tasna OCT. One consequence is that across this high $\left(\mathrm{T}_{2}\right)$, the TPRS can be locally eroded and the BPRS may not be recorded (Fig. 6).

The exhumation domain $\left(\mathrm{T}_{3}\right.$ level) on the upper plate margin has, with the exception of the Newfoundland margin, never been drilled and little is known about the structure and stratigraphic evolution of this domain. While Masini et al. (2013) suggested that this domain remains over a stable, continentward dipping exhumation fault, Gillard et al. (2015) showed, using the example of the southern Australian margin that exhumation systems in upper plate margins are unstable and step oceanwards. This would explain the observed down(on)lapping of the syn-exhumation 
sediments in this domain (see Figs 3 and 4). For the Alps, Decarlis et al. (2015) showed that within the exhumation domain $\left(\mathrm{T}_{3}\right.$ level), the TPRS is, if present, discontinuous and occurs only in allochthonous blocks (see also review paper of Beltrando et al. 2014). The fact that the most distal parts are sediment-starved makes that the BPRS is very deep and some of the basement highs are passively onlapped/sealed by post rift sediments. This is the case for the Tasna OCT (Fig. 5e) where the post-rift sediments directly overlie an exhumation surface. In examples with higher sedimentation rates (e.g. ION IE1-1000 section), syn-tectonic packages can be observed forming locale growth structures over tilted blocks. However, most of the sediments in this domain show passive infill and down(on)lap onto basement (see also Gillard et al., 2015).

\subsection{Stratigraphic horizons and correlations across an upper-plate margin}

4.2.1 A tectono-stratigraphic model for a magma-poor rifted margin

In order to define a tectono-stratigraphic model, first order stratigraphic horizons need to be defined. In this study we defined the Top Pre-Rift Sequence (TPRS), the Top Syn-Tectonic Sequence (TSTS), and the Base Post-Rift Sequence (BPRS) (Fig. 6). The terms "pre-rift", "synrift" and "post-rift" are used as time intervals, defining onset and termination of a rift system, the latter defined by the onset of steady state seafloor spreading. As a consequence the TPRS and the BPRS can be considered as isochrones. However, while the final lithospheric breakup is considered to be unique, i.e. it occurs only once in the lifetime of a rift system; the onset of rifting is more difficult to define and in poly-phase rift systems, different rift events can be defined, leading to different TPRS horizons (see examples of the Iberia and Alpine rift systems). In contrast to present-day margins, where the TPRS and the BPRS correspond to reflections in 
seismic lines, in the Alps their definition and in particular their correlation is mainly based on age data and/or lithostratigraphic considerations.

\subsubsection{First order correlation of TPRS, TSTS and BPRS across an upper plate margin}

The TPRS typically occurs over top basement in the proximal margin ( $\mathrm{T}_{1}$ level). It shows, ideally, a wide lateral continuity, constant thickness and consists typically of sediments originating from sub-areal to shallow marine depositional environments. At some margins (e.g. Iberia-Newfoundland and Alpine Tethys) the TPRS is more difficult to define due to the polyphase and/or protracted history of the rift system. For these margins, two or more TPRS can be defined. Due to the lack of good seismic and drill hole data, the TPRS is more difficult to define in distal parts of the margin. In the example of the Briançonnais, the TPRS is uplifted and partly eroded during early rifting. In the most distal parts of the Alpine margin ( $\mathrm{T}_{3}$ level) the TPRS is discontinuous and occurs only locally as extensional allochthons overlying exhumed crustal or mantle rocks (see Err nappe in the Alps, or ODP Site 1069 block offshore Iberia; Manatschal et al. (2007)).

The BPRS is defined as the first sedimentary sequence overlying the first oceanic crust at the BP. The correlation of this reflection continent ward enables to define the base of the post-rift sequence. In the East Indian ION-1000 line, the BPRS can be mapped from the BP to $\mathrm{km} 40$ as one continuous reflection. Its correlation further continent ward is difficult (Fig.3d). However, from the observations made in the Alps, where the BPRS is formed by Radiolarian cherts, it is clear that this level does not coincide with the sediments that cap the fault-bounded basins in the distal margin (Masini et al., 2013). This has also been shown for the Iberia-Newfoundland 
margins, where the BPRS corresponds to the Aptian/Albian horizon, which lies in the proximal margin in the post-tectonic sequence (Alves et al., 2006).

The TSTS corresponds to the horizon capping the syn-tectonic sequences across the margin. Masini et al. (2013) showed that the TSTS is well defined in the proximal margin, where it corresponds to an event that we refer to as the Necking Unconformity (NU; for a more detailed discussion see below). For the distal lower plate margin, Péron-Pinvidic et al. (2007), Ranero and Pérez-Gussinyé (2010), and Masini et al. (2013) showed that the TSTS is getting younger ocean wards. The TSTS splits the syn-rift sequence into two parts: 1) a lower part floored by the TPRS and limited at its top by the TSTS that corresponds to a true syn-tectonic sequence, i.e. a sequence that contain tectonic growth structures, and 2) an upper part that is floored by the TSTS and limited at its top by the BPRS. This sequence, although part of the syn-rift sequence, does not show any evidence of syn-tectonic structures and it is referred to as the "sag sequence". It is fundamental to note that the TSTS is diachronous across the margin and that syn-tectonic sequences are not of the same age across the margin.

The TSTS, separating a syn-tectonic from a sag-sequence, has been defined on lower plate margins (Masini et al., 2013; Péron-Pinvidic et al., 2007) but it has not been discussed for upperplate margins. The major problem to distinguish the syn-tectonic and sag sequences at upper plate margins is that the sedimentary succession over the $\mathrm{T}_{2}$ level is often reduced or eroded, in the latter case coinciding with an unconformity (e.g. India and Alpine examples; Figs. 3 and 5). Indeed, for these examples the TSTS corresponds to a hiatus/unconformity. The nature of this unconformity seems to be the result of two processes: 1) uplift and erosion that occur during the syn-tectonic phase that is responsible for the erosional unconformity, and 2) passive infill on the edges of the high during deposition of the "sag" (post-tectonic) sequence (see Fig. 3). These two 
processes result in a major unconformity/hiatus over $\mathrm{T}_{2}$, which makes that correlation between the $\mathrm{T}_{1}$ and $\mathrm{T}_{3}$ levels is difficult at many margins.

At the $T_{3}$ level, syn-tectonic sequences can be defined. In the ION IE1-1000 section (Fig. 3), the syn-tectonic sedimentary wedges seem to get younger oceanwards. They overlie remnants of continental blocks and/or pre-rift sediments further continentwards and exhumed mantle with variable amounts of magmatic additions further oceanwards. In the SCREECH 2 section (Fig. 4), it can be observed that a post-tectonic sequence develops oceanwards into a pre-tectonic sequence. This depositional pattern is very similar to that observed along the southern Australia margin (Gillard et al. 2015). The major characteristic is the oceanward down(on)lapping onto basement resulting in a younging of the first sediments overlying basement. This geometry can be explained by either the existence of a basement high at the future distal margin (would result in an onlapping), or by the creation of new real estate (would result in a downlapping). In the case of SHREECH 2 and the Tasna examples, the existence of exhumed material (new real estate) at the $T_{3}$ level is supported by drilling and field observations respectively. At both, the ION IE11000 and SCREECH 2 sections, sedimentary sequences can be defined at the $\mathrm{T}_{3}$ level that are post-tectonic but pre-dates the BPRS, corresponding to sag-sequences. The sag sequences wedge out oceanwards and show similar geometries as described on lower plate margins (e.g. PéronPinvidic et al., 2007; Masini et al., 2012 and 2013). This observation suggests that the creation of accommodation space at the $\mathrm{T}_{3}$ level is symmetric and not, as commonly proposed, asymmetric. Another point that is important and needs to be discussed is the control of the relative rates of sedimentation relative to the rates of creation of accommodation space controlling the stratigraphic architecture of deep-water rifted margins. 


\subsection{Tectono-stratigraphic evolution of an upper-plate margin: a conceptual model}

Fig. 7 shows a sequential, conceptualized restoration of the section shown in Fig. 2 that displays different stages of rifting from the onset of stretching (TPRS), to the onset of necking (NU), to coupling (CP), to exhumation (EP), and finally to breakup and seafloor spreading (BP and BPRS). This sequential restoration is similar to that proposed by Sutra et al. (2013), but in this study we include the restoration of stratigraphic marker horizons and their relation to the main extensional structures. Four points are important to consider: 1) the two future conjugate margins develop through an asymmetric evolution only between the coupling and early stage of exhumation, while during the rest of their evolution their evolution is symmetric, 2) there is a direct link between the formation of the $\mathrm{CP}$ and the $\mathrm{NU}, 3$ ) during asymmetric migration between coupling and exhumation the stratigraphic evolution of the two margins is very different and asymmetric, and 4) during exhumation between the EP and the BP the stratigraphic evolution is controlled by the oceanward migration of deformation at both margins. The conceptual model shows the time-space evolution of the stratigraphic marker horizons and their final position in a passive margin. 


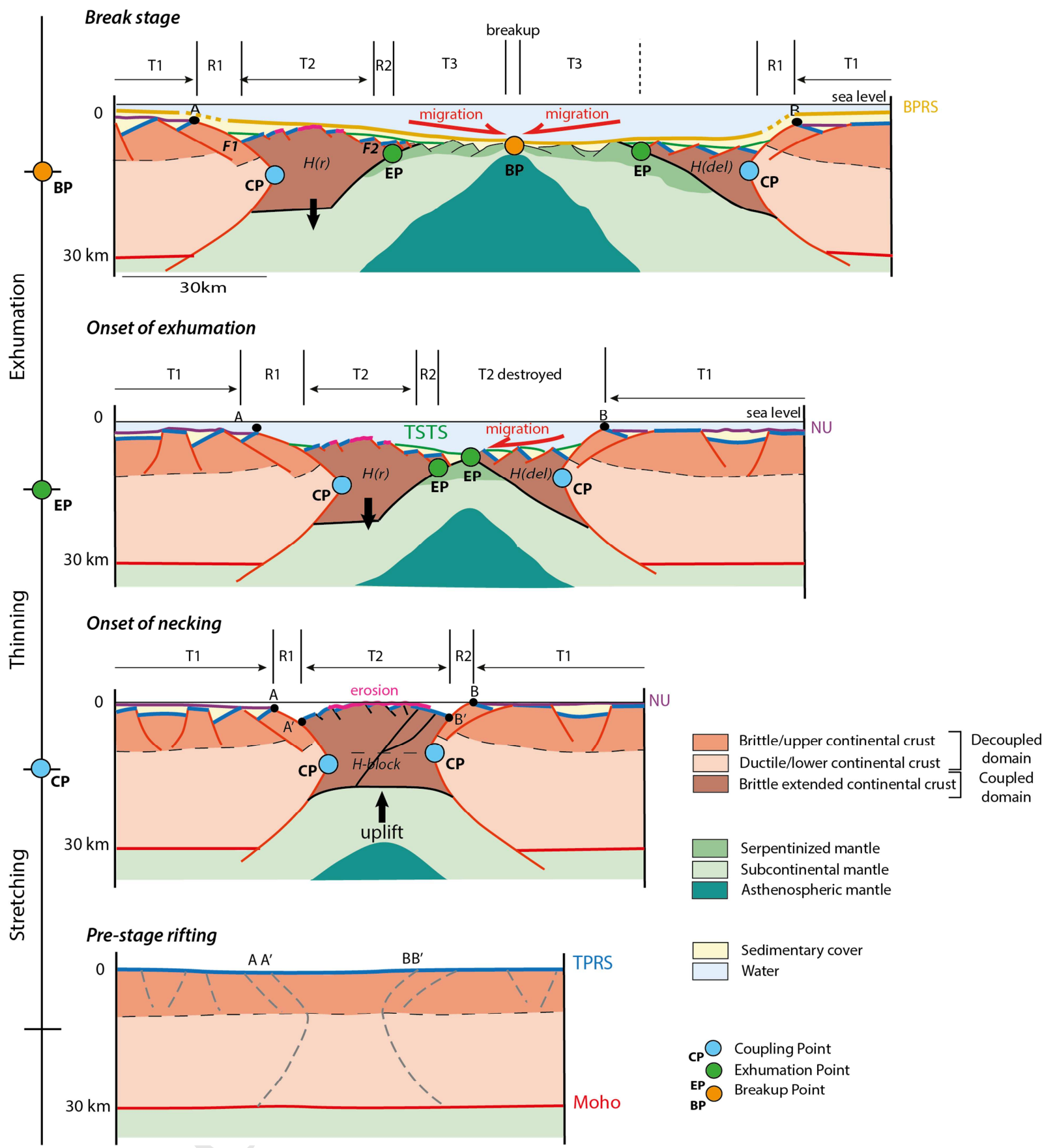

Fig.7 Conceptual 2D kinematic model showing the time-space evolution of the upper and lower plate conjugate rifted margins. From bottom to top four stages of the evolution are shown, initiating with the pre-rift stage characterized by an initial crustal thickness and a continuous TPRS. The next stage shows the onset of coupling, characterized by uplift and erosion of the future distal margin (H-block) and the formation of a major necking unconformity across the future proximal margin. At the onset of the 
exhumation stage the margin has acquired its maximal asymmetry and the depositional systems at the upper and lower plate are very different. While the upper plate (residual H-block) is relatively little deformed during the final stage of rifting and strongly subsides, the lower plate (delaminated H-block) is more severely deformed during final rifting and the syn-tectonic sequence migrates oceanwards (e.g. Mohn et al. 2012). During the breakup stage, exhumation is symmetric, as indicated by the oceanward migration of the syn-tectonic sediments on both conjugate. It is important to note that an asymmetric evolution of the margin is only observed between the coupling and the early exhumation stage. Therefore, the upper - lower plate concept can only be applied between the $\mathrm{CP}$ and the $\mathrm{EP}$, which is a transient stage in the evolution of a margin. As a consequence, an upper plate margin is characterized by the occurrence of a staircase architecture of the top basement, with 3 terraces $\left(T_{1}, T_{2}, T_{3}\right)$ separated by two major ramps $\left(R_{1}\right.$ and $\left.R_{2}\right)$. In contrast a lower plate margin does not preserve a $T_{2}$ terrace and a $R_{2}$ ramp.

Fig. 8 shows the time-space relationships of the different time markers, which are the TPRS, the TSTS/NU, and the BPRS. The TSTS, which separates a syn-tectonic sequence from a sag sequence between the TPRS and BPRS is not an isochron in the distal margin. It is also important to note that at most margins the BPRS was commonly assumed to cap the rift structures in the proximal margin ( $\mathrm{T}_{1}$ level) and the rifting event was considered to be single-phased and widespread, thus, the BPRS was referred to as the "breakup unconformity".

Observations from the Iberia-Newfoundland and Alpine margins clearly show that the BPRS is much higher in the stratigraphic section as previously assumed in the proximal margin. Another important observation is that, as a general rule, all basins overlying little extended crust (proximal domain) stop their tectonic activity when necking initiates. The so-called necking unconformity (NU) has been used to define the age of necking in the North Atlantic (Chenin et al. 2015). The idea behind the definition of the NU is that necking occurs when the strongest layer in the 
lithosphere breaks and that subsequent deformation occurs only over the area where the strongest layer broke. In rift systems where the initial thermal conditions are equilibrated $\left(\leq 650^{\circ} \mathrm{C}\right.$ at base lithosphere, Lavier and Manatschal, 2006) this may occur over the area and at the moment when the upper lithospheric mantle yields, giving rise to the subsequent localization of deformation over this domain.

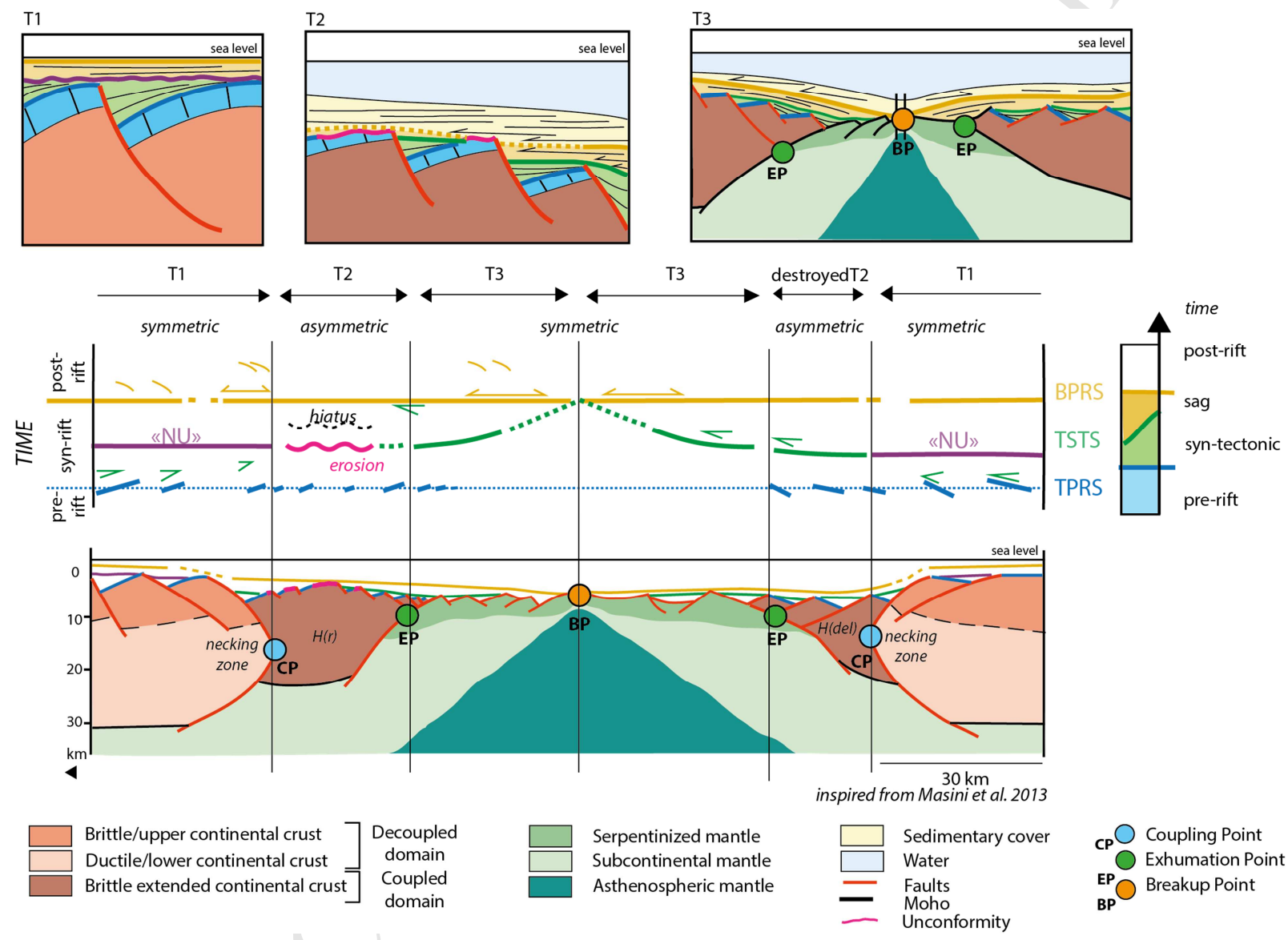

Fig.8 Stratigraphic model for a magma-poor rifted margin showing the first order stratigraphic architecture of different parts of a rifted margin and the distribution of TPRS, TSTS (including NU) and the BPRS across the margin.

While the tectono-stratigraphic evolution of the proximal and the distal lower plate margins are described by Masini et al. (2013), the evolution of the distal upper plate margin is not captured by 
their model. In respect to their model, major differences concern the $T_{2}$ and $T_{3}$ levels in the upper plate margin. The stratigraphic evolution observed at the $T_{2}$ level includes two processes: 1) uplift during the thinning stage that can explain the erosion and formation of toplaps observed across the $\mathrm{T}_{2}$ level. It is important to note that no evidence for uplift and erosion can be observed over the proximal parts $\left(\mathrm{T}_{1}\right.$ levels), indicating that erosion over the $\mathrm{T}_{2}$ level cannot be due to global sea level drop or large scale dynamic topography (see discussion below).

A second important observation is that at the $\mathrm{T}_{3}$ level the deformation migrates outboard, as indicated by the ocean ward migration of the TSTS and the wedging of the "sag" formation in the same direction. This indicates that mantle exhumation cannot be explained by asymmetric insequence stepping of normal faults as suggested by (Ranero and Pérez-Gussinyé, 2010; Masini et al., 2013; Brune et al., 2014). A more likely mechanism is out of sequence faulting suggested by Reston (2007) and Reston and McDermott (2011) or Gillard et al. (2015).

\subsection{Controls on sediment architecture on upper plate margins}

The stair-type architecture of upper plate margins, described by terraces $\left(T_{1}, T_{2}\right.$, and $\left.T_{3}\right)$, ramps/faults $\left(\mathrm{R}_{1} / \mathrm{F}_{1}\right.$ and $\left.\mathrm{R}_{2} / \mathrm{F}_{2}\right)$, and domain boundaries $(\mathrm{CP}, \mathrm{EP}, \mathrm{BP})$ is a direct result of a succession of rift modes (e.g. stretching, thinning and exhumation) within a localizing extensional system that is magma-poor. In such a system, the stratigraphic architecture can be described by key stratigraphic marker horizons that are the TPRS, the NU, the TSTS and the BPRS (see Figs 7 and 8). However, this first order description of the stratigraphic architecture is 2D and does not account for: 1) architectural variability, 2) creation of accommodation space, and

3) filling of accommodation space. While the first two are mainly controlled by tectonic 
processes, the last one depends on sedimentary processes as well the production and availability of sediments.

\section{Architectural variability}

As shown by Huismans \& Beaumont (2002), the architectural variability depends, on a first order, on the inheritance and the rift induced processes, in particular the occurrence or absence of ductile layers, rates of extension, potential to create magma (Fig. 9a; Manatschal et al., 2015). Thus, not all rifted margins go through asymmetric stages and consequently define upper plate margins. Along strike changes make that at the transition between an upper and a lower plate margin, the rift architecture can be complex (see Péron-Pinvidic et al. 2015). Moreover, the occurrence of magma may not only mask the pre-magmatic evolution of the margin, but it may also change and control the rift evolution. Another important factor is the occurrence of strong inheritance (Manatschal et al., 2015) or oblique extension (Jammes et al., 2010) that have the tendency to accentuate the symmetry or asymmetry of the margin during the necking stage. Thus, not all margins show upper and lower plate geometries as described in this paper, and along strike variations, including various widths of necking zones, need to be considered. However, the fact that the range of rheologies and strain rates are limited in geological systems may explain that many orthogonal, magma-poor margins show similar crustal scale architectures with upper and lower plate margins (e.g. Mohn et al. (2012)). This is not only true for natural examples but also for dynamic and analogue models (Beslier and Brun, 1991; Brun and Beslier, 1996; Huismans and Beaumont, 2002; Lavier and Manatschal, 2006; Brune et al., 2014). 


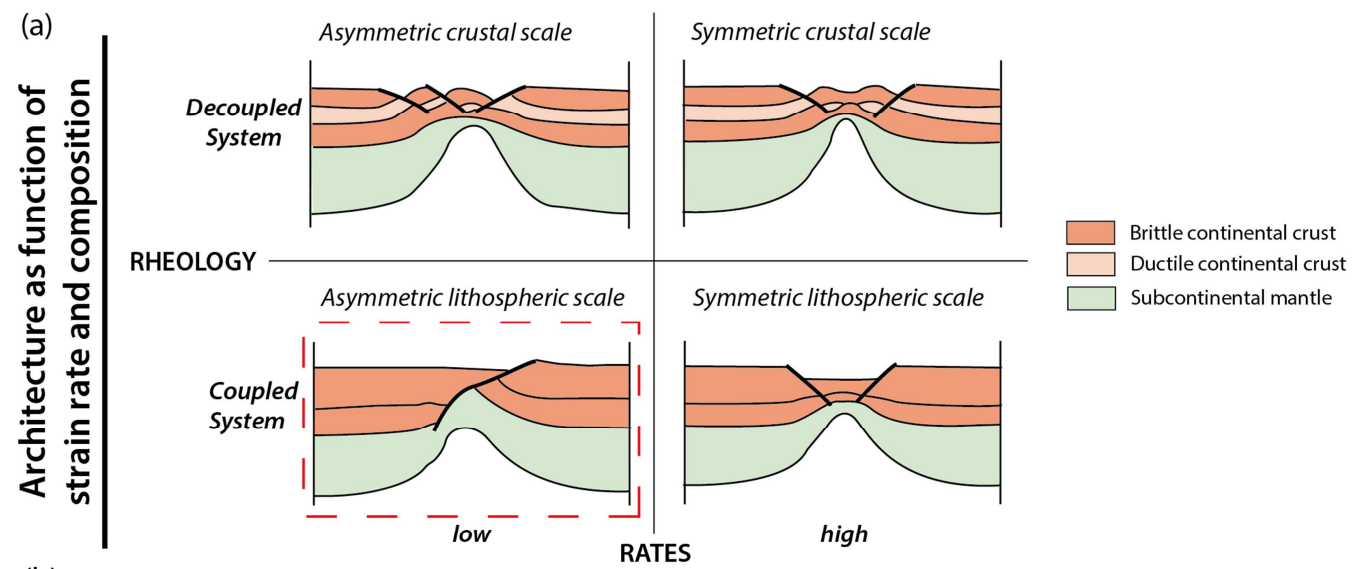

(b)
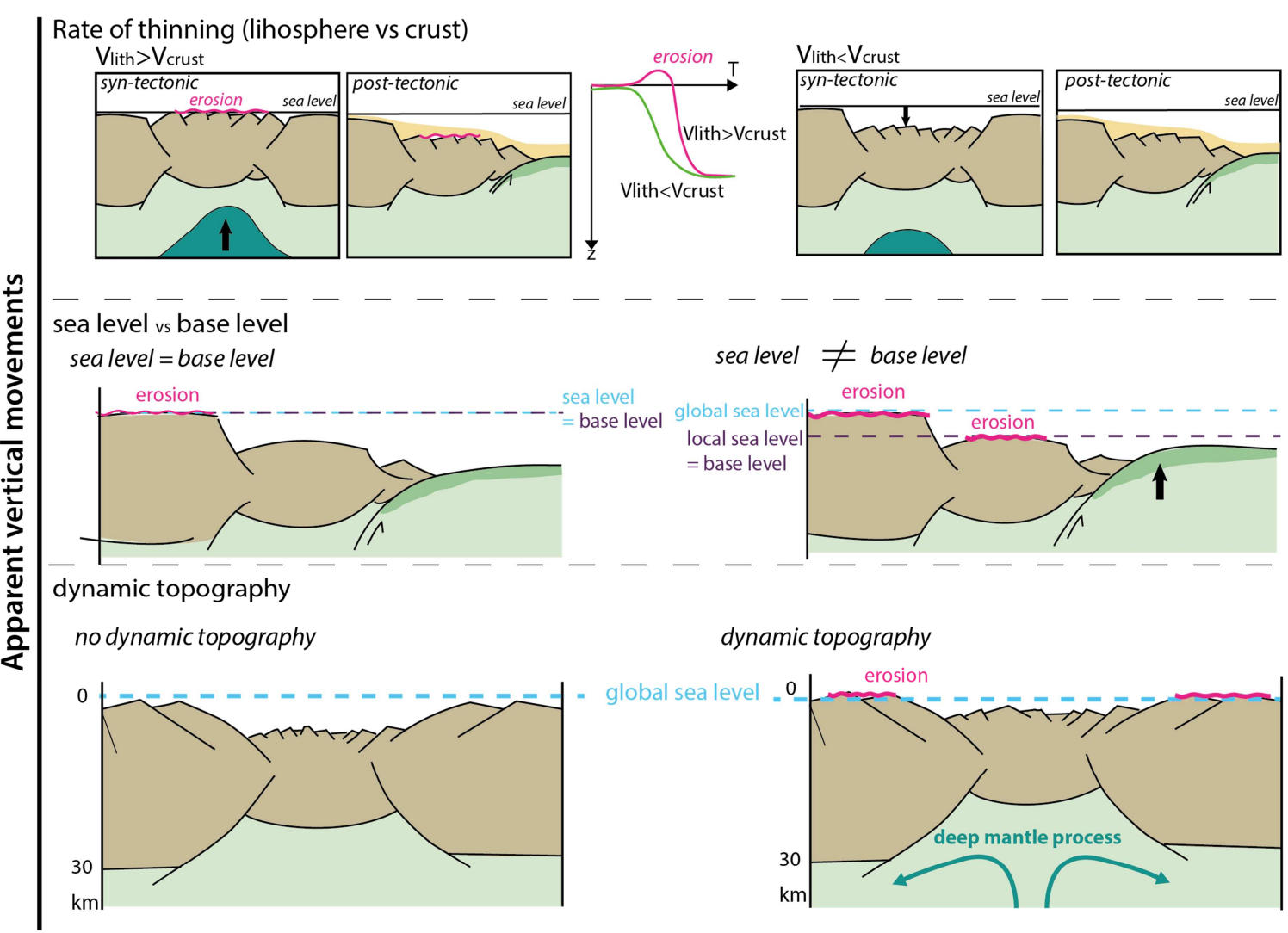

sealevel $\neq$ baselevel

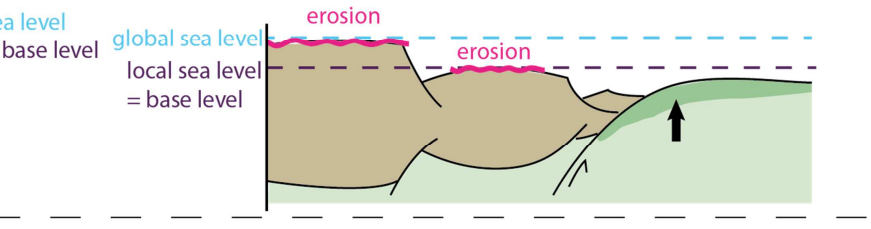

dynamic topography

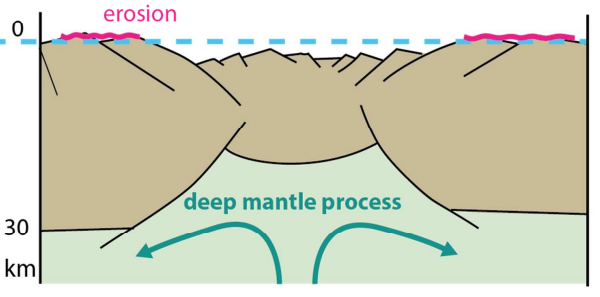

(c)

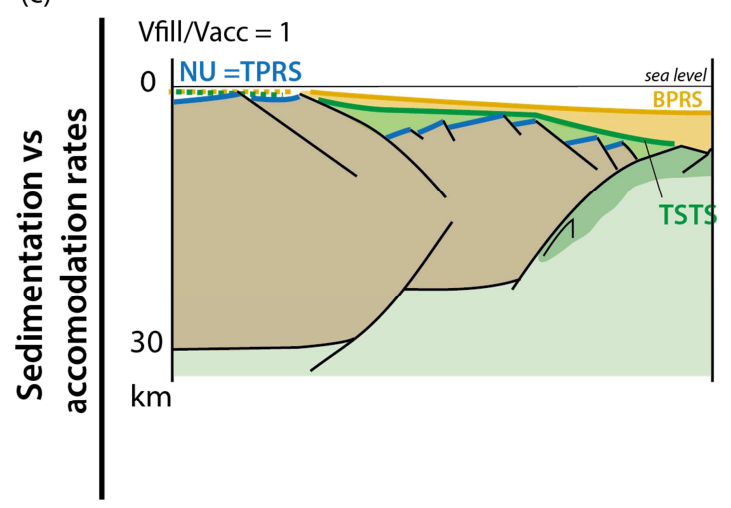

$\mathrm{NU}=\mathrm{BPRS}$

Vfill/Nacc $<<1$

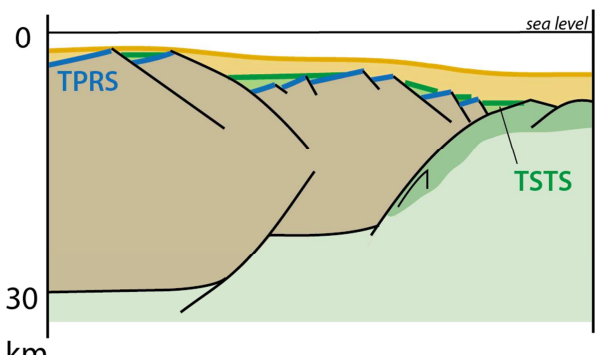


Fig. 9 a) Architectural variability of magma-poor rifted margins depending on rates of extension and rheology (modified from Huismans and Beaumont, 2002). b) Factors/processes that control apparent vertical movements and create accommodation space. c) The role of sedimentation rates relative to extension rates in controlling the stratigraphic architecture of rifted margins (NU : necking unconformity, TPRS : Top of Pre-rift Sequence, TSTS : Top of Syn-tectonic Sequence, BPRS : Base of Post-rift Sequence). For explanations see text.

\section{Creation of accommodation space}

Key parameters defining the creation of accommodation space are the thinning of the crust $\left(\mathrm{v}_{\text {crust }}\right)$ and lithosphere $\left(\mathrm{v}_{\text {lith }}\right)$ as well as changes in base level. The former depends on rates and localization of thinning, which are different for the crust (mechanical-magmatic) and the lithosphere (thermal). While in the McKenzie model (McKenzie, 1978) the two are supposed to be coupled, in the "real world" they can be decoupled leading to two end member cases where $v_{\text {lith }}>v_{\text {crust }}$ or $v_{\text {lith }}<v_{\text {crust }}$ with major implications for the subsidence history (Fig. 9b). In the case of $\mathrm{v}_{\text {lith }}>\mathrm{v}_{\text {crust }}$ the rise of the lithosphere can partly counterbalance the subsidence due to crustal thinning and the accommodation space created during syn-tectonic thinning is smaller and the post-tectonic subsidence that is related to the cooling of the lithosphere, will be more important. For the opposite case $\left(\mathrm{v}_{\text {lith }}<\mathrm{v}_{\text {crust }}\right)$, the amount of syn-tectonic subsidence respective to posttectonic subsidence is minor.

Another, important factor controlling the creation of accommodation space is the sea-level relative to the base level. In some examples (potential candidates are the central segment of the South Atlantic north of the Walvis Ridge or the Gulf of Mexico (Karner and Watts, 1982; Karner and Driscoll, 1999; Pindell and Kennan, 2009) sea-level can be below global base level, leading to air filled holes. The best example is the Messinian of the Mediterranean (Cornée et al., 1994). 
In order to create such extreme conditions, separation, or isolation of basins and elevated evaporation are necessary, conditions that are likely to happen during early stages of hyperextension, when basins are segmented and not yet connected to the global ocean. In such systems the control of the accommodation space is more complex and not a simple control of tectonic subsidence. Since these systems are often associated with evaporites, their recognition is quite simple.

Another process that may be important in controlling creation of accommodation space is dynamic topography, which is related to deep mantle processes (Burgess et al., 1997; White and Duncan, 1996). Since this process is, by definition, related to large-scale anomalous uplift or subsidence it can easily be detected at the proximal margins (Fig.9b). In the case of positive dynamic topography, it should be expected that the proximal parts of the margins should be uplifted and eroded during such events (e.g. Sinai, Kohn and Eyal (1981). Vertical movements such as those observed in the Briançonnais domain $\left(\mathrm{T}_{2}\right.$ level) cannot be explained by dynamic topography, since uplift is limited to the future distal parts of the margin ( $T_{2}$ levels) and no erosional unconformity is observed over the proximal parts ( $\mathrm{T}_{1}$ levels) (Fig.9b).

\section{Filling of accommodation space}

A key factor defining the stratigraphic architecture in seismic sections is the relative rates of creation of accommodation space $\left(\mathrm{v}_{\mathrm{acc}}\right)$ and sediment infill $\left(\mathrm{v}_{\text {inf }}\right)$ also referred to the "A/S ratio concept" of Muto and Steel (1997). The relative velocities control the continuity of markers. In the case of $\mathrm{v}_{\text {inf }} / \mathrm{v}_{\mathrm{acc}}=1$ (filled basin) stratigraphic markers tend to be continuous and correlations are simple (Fig. 9c). In contrast, in the case of $\mathrm{v}_{\text {inf }} / \mathrm{v}_{\text {acc }}<<1$ (underfilled basins) correlations are more difficult and the first order architecture of the basin is more complex. In the case of strong 
sediment starvation (see Alpine and Iberia Newfoundland examples), unconformities are more pronounced. In such cases the BPRS goes very deep and the sag-sequence is very thin or absent (Fig. 9c). In the case where sedimentation rates are high, TSTS can correspond to the BPRS in the proximal margin, but oceanwards, over T2 and in particular over T3, a thick sag formation can be identified.

\section{Conclusions}

The aim of this contribution was to provide a first order description of the stratigraphic and crustal architecture of an upper plate magma-poor rifted margin, develop a methodology to integrate different data/observations, and propose a first order tectono-stratigraphic model to describe the evolution of these margins. In order to propose such a model, we used the seismic section ION IE1-1000 from the East Indian margin that we consider as the champion line imaging upper plate magma-poor rifted margins; the SCREECH 2 section across the Newfoundland margin that had been drilled at the oceanward end during ODP Leg 210 and kmscale outcrops from the European margin today exposed in the Western and Central Alps. The observations of these present-day and fossil margins permit us to define key morpho-tectonic characteristics of margins that are: terraces $\left(T_{1}, T_{2}\right.$ and $\left.T_{3}\right)$, ramps $\left(R_{1}\right.$ and $\left.R_{2}\right)$ and the location of coupling between crustal and mantle layers (e.g. coupling point, CP), exhumation of mantle (EP), and breakup (BP). Moreover, we defined key stratigraphic levels that are the Top Pre-Rift Sequence (TPRS) and the Base of the Post Rift Sequence (BPRS) that we consider as time markers. In between these two time markers we define the Top of the Syn-Tectonic Sequence (TSTS) that separates sedimentary packages that show evidence for growth structures (syntectonic sequence) from sediments that show passive infill, but are pre-breakup defined as the sag 
sequence. It is important to note that the TSTS is not an isochron and has the tendency of getting younger oceanwards. The description of these few, first order levels enables to describe the temporal and spatial evolution of the rifting process along an upper plate margin. Our observations suggest that the evolution of these margins evolve through a stage of localization and uplift of the margin that predates fast subsidence and delamination of the future distal margin leading to the development of a major, late fault system delimiting a basement high from an exhumation system that is at abyssal depth. This evolution leads to two major characteristics of upper plate margins: the staircase type architecture of upper plate margins and the distinct structural and stratigraphic architecture that is linked to each of the terraces $\left(T_{1}, T_{2}\right.$ and $\left.T_{3}\right)$ and intermediate ramps $\left(\mathrm{R}_{1}\right.$ and $\left.\mathrm{R}_{2}\right)$. These first order relationships can be used to define upper plate margins and to establish their tectono-sedimentary evolution. These relationships are best preserved in margins with low magmatic budget and high sedimentation rates. In margins with high magmatic budgets or very low sedimentation rates these observations may be more difficult to be done.

\section{Acknowledgements}

We thank Total for the support of the research project and ION-GXTechnology for permitting publication of the ION IE1-1000 line from the East Indian margin. The authors acknowledge the constructive and helpful reviews of Per Terje Osmundsen and an anonymous reviewer. 


\section{Reference}

Acharyya, S.K., 1998. Break-up of the greater Indo-Australian continent and accretion of blocks framing south and east Asia. J. Geodyn. 26, 149-170.

Alves, T.M., Moita, C., Cunha, T., Ullnaess, M., Myklebust, R., Monteiro, J.H., Manuppella, G., 2009. Diachronous evolution of Late Jurassic-Cretaceous continental rifting in the northeast Atlantic (west Iberian margin). Tectonics 28.

Alves, T.M., Moita, C., Sandnes, F., Cunha, T., Monteiro, J.H., Pinheiro, L.M., 2006. Mesozoic-Cenozoic evolution of North Atlantic continental-slope basins: The Peniche basin, western Iberian margin. AAPG Bull. 90, 31-60.

Argand, E., 1920. Plissements précurseurs et plissements tardifs des chaines de montagnes.

Argand, E., 1916. Sur l'arc des Alpes occidentales. Schweiz. Geolog. Ges.

Argand, E., 1911. Les nappes de recouvrement des Alpes occidentales. Carte Struct. Coupes Beitr Geol Kt. Schweiz Spezialkarte 64.

Barbier, R., Bloch, J.-P., Debelmas, J., Ellenberger, F., Fabre, J., Feys, R., Gidon, M., Goguel, J., Gubler, Y., Lanteaume, M., 1963. Problèmes paléogéographiques et structuraux dans les zones internes des Alpes occidentales entre Savoie et Méditerranée. Livre Mém P Fallot 2, 331-377.

Barfety, J., 1965. Etude géologique des environs du Monétier-les-Bains (HA)(Zones subbriançonnaise et briançonnaise)-Alpes françaises. Université de Grenoble.

Barféty, J.C., Bordet, P., Carme, F., Debelmas, J., Meloux, M., Montjuvent, G., Mouterde, R., SarrotReynauld, J., 1972. Notice explicative, carte géologique de la France (1/50.000), feuille Vizille (797). BRGM Orléans.

Barféty, J.-C., Gidon, M., 1984. Un exemple de sédimentation sur un abrupt de faille fossile: le Lias du versant Est du massif du Taillefer (Zone dauphinoise, Alpes occidentales). Rev. Géographie Phys. Géologie Dyn. 25, 267-276.

Barféty, J.C., Gidon, M., Montjuvent, G., 1970. Extension et importance des glissements superficiels aux abords méridionaux de Grenoble. Geol. Alp 46, 17-22.

Baud, A., 1976. Les terriers de Crustacés décapodes et l'origine de certains faciès du Trias carbonaté. Eclogae Geol. Helvetiae 69, 415-424.

Baud, A., Masson, H., 1975. Preuves d'une tectonique liasique de disetnsion dans le sdomaine briançonnais. Eclogae Geol. Helvetiae 68, 131-145.

Baud, A., Megard-Galli, J., 1975. Evolution d'un bassin carbonaté du domaine alpin durant la phase préocéanique: cycles et séquences dans le Trias de la zone briançonnaise des Alpes occidentales et des Préalpes.

Bellahsen, N., Jolivet, L., Lacombe, O., Bellanger, M., Boutoux, A., Garcia, S., Mouthereau, F., Le Pourhiet, L., Gumiaux, C., 2012. Mechanisms of margin inversion in the external Western Alps: Implications for crustal rheology. Tectonophysics 560-561, 62-83. doi:10.1016/j.tecto.2012.06.022

Bertle, R.J., 2004. The sedimentary record of North Penninic Schistes Lustrés of the Lower Engadine Window and its correlation to the Tauern Window (Eastern Alps). Jahrb. Geol. Bundesanst. Wien 144, 165-171.

Beslier, M.-O., Brun, J.-P., 1991. Boudinage de la lithosphère et formation des marges passives. Comptes Rendus Académie Sci. Sér. 2 Mécanique Phys. Chim. Sci. Univers Sci. Terre 313, 951-958.

Beslier, M.-O., Cornen, G., Sawyer, D.S., Whitmarsh, R.B., Klaus, A., Collins, E.S., Comas, M.C., de Kaenel, E., Gervais, E., Gibson, I., 1994. Péridotites et gabbros à la transition continent-océan d'une marge passive: résultats préliminaires du Leg ODP 149 dans la Plaine Abyssa le Ibérique. Comptes Rendus Académie Sci. Sér. 2 Sci. Terre Planètes 319, 1223-1229. 
Bill, M., O'Dogherty, L., Guex, J., Baumgartner, P.O., Masson, H., 2001. Radiolarite ages in AlpineMediterranean ophiolites: Constraints on the oceanic spreading and the Tethys-Atlantic connection. Geol. Soc. Am. Bull. 113, 129-143.

Boillot, G., Froitzheim, N., 2001. Non-volcanic rifted margins, continental break-up and the onset of seafloor spreading: some outstanding questions. Geol. Soc. Lond. Spec. Publ. 187, 9-30. doi:10.1144/GSL.SP.2001.187.01.02

Boillot, G., Recq, M., Winterer, E.L., Meyer, A.W., Applegate, J., Baltuck, M., Bergen, J.A., Comas, M.C., Davies, T.A., Dunham, K., 1987. Tectonic denudation of the upper mantle along passive margins: a model based on drilling results (ODP leg 103, western Galicia margin, Spain). Tectonophysics 132, 335-342.

Bourbon, M., 1980. Evolution d'un secteur de la marge nord-téthysienne en milieu pélagique: la zone briançonnaise près de Briançon entre le début du Malm et l'Eocène inférieur. Université Louis Pasteur-Strasbourg I.

Bourbon, M., 1977. Reconstitution paleomorphologique de fonds marins sur la marge nord-tethysienne; le Jurassique superieur et le Cretace brianconnais externes pres de Briancon. Bull. Soc. Geol. Fr. 729-733.

Bourbon, M., 1972. Example of condensed pelagic series with rapid thickness variations in Briançon mal sections of Condamine West of Briançon (Hautes-Alpes). COMPTES RENDUS Hebd. SEANCES Acad. Sci. Ser. D 274, 2631-\&.

Bourbon, M., 1971. Contribution à l'étude sédimentologique et géochimique des lacunes et des condensations de la série pélagique briançonnaise.

Bronner, A., Sauter, D., Manatschal, G., Péron-Pinvidic, G., Munschy, M., 2011. Magmatic breakup as an explanation for magnetic anomalies at magma-poor rifted margins. Nat. Geosci. 4, 549-553. doi:10.1038/ngeo1201

Brune, S., Heine, C., Pérez-Gussinyé, M., Sobolev, S.V., 2014. Rift migration explains continental margin asymmetry and crustal hyper-extension. Nat. Commun. 5. doi:10.1038/ncomms5014

Brun, J.P., Beslier, M.O., 1996. Mantle exhumation at passive margins. Earth Planet. Sci. Lett. 142, 161173.

Buck, W.R., 1991. Modes of continental lithospheric extension. J. Geophys. Res. Solid Earth 1978-2012 96, 20161-20178.

Buck, W.R., Martinez, F., Steckler, M.S., Cochran, J.R., 1988. Thermal consequences of lithospheric extension: pure and simple. Tectonics 7, 213-234.

Burgess, P.M., Gurnis, M., Moresi, L., 1997. Formation of sequences in the cratonic interior of North America by interaction between mantle, eustatic, and stratigraphic processes. Geol. Soc. Am. Bull. 109, 1515-1535.

Chenin, P., Manatschal, G., Lavier, L. L., \& Erratt, D. (2015). Assessing the impact of orogenic inheritance on the architecture, timing and magmatic budget of the North Atlantic rift system: a mapping approach. Journal of the Geological Society, 2014-139.

Chevalier, F., Guiraud, M., Garcia, J.-P., Dommergues, J.-L., Quesne, D., Allemand, P., Dumont, T., 2003. Calculating the long-term displacement rates of a normal fault from the high-resolution stratigraphic record (early Tethyan rifting, French Alps). Terra Nova 15, 410-416. doi:10.1046/j.1365-3121.2003.00508.x

Claudel, M.E., 1999. Reconstitution paléogéographique du domaine Briançonnais au Mésozoïque. Ouvertures océaniques et raccourcissements croisés. Université Joseph Fourier Grenoble 1, Grenoble.

Claudel, M.E., Dumont, T., 1999. A record of multistage continental break-up on the Briançonnais marginal plateau (Western Alps) : Early nd Middle-Late Jurassic rifting. Eclogae Geol. Helvetiae 92, 45-61. doi:0012-9402/99/010045-17\$1.50+0.20/0 
Cornée, J.-J., Saint Martin, J.-P., Conesa, G., Muller, J., 1994. Geometry, palaeoenvironments and relative sea-level (accommodation space) changes in the Messinian Murdjadjo carbonate platform (Oran, western Algeria): consequences. Sediment. Geol. 89, 143-158.

Crittenden, M.D., Coney, P.J., Davis, G.H., Davis, G.H., 1980. Cordilleran metamorphic core complexes. Geological Society of America.

Curray, J.R., Emmel, F.J., Moore, D.G., Raitt, R.W., 1982. Structure, tectonics, and geological history of the northeastern Indian Ocean. Springer.

Davis, G.H., 1983. Shear-zone model for the origin of metamorphic core complexes. Geology 11, 342347.

Decarlis, A., Manatschal, G., Haupert, I., \& Masini, E. (2015). The tectono-stratigraphic evolution of distal, hyper-extended magma-poor conjugate rifted margins: Examples from the Alpine Tethys and Newfoundland-Iberia. Marine and Petroleum Geology.

Debelmas, J., 1987. Le détritisme lié à l'émersion du domaine Brianconnais au début du Mésozoïque. Géologie Alp.

Debelmas, J., 1983. La formation des Alpes. La recherche 14, 1542-1552.

Debelmas, J., 1955. Les zones subbriançonnaise et brianconnaise occidentale entre Vallouise et Guillestre (Hautes-Alpes).

De Graciansky, P.C., Auffret, G.A., Dupeuble, P., Montadert, L., Müller, C., 1979. Interpretation of depositional environments of the Aptian/Albian black shales on the north margin of the Bay of Biscay (DSDP Sites 400 and 402). Montadert Roberts DG Al Init Repts DSDP 48, 877-908.

Dick, H.J., Lin, J., Schouten, H., 2003. An ultraslow-spreading class of ocean ridge. Nature 426, 405-412.

Driscoll, N.W., Karner, G.D., 1998. Lower crustal extension across the Northern Carnarvon basin, Australia: Evidence for an eastward dipping detachment. J. Geophys. Res. Solid Earth 1978-2012 103, 4975-4991.

Dumont, T., Champagnac, J.-D., Crouzet, C., Rochat, P., 2008. Multistage shortening in the Dauphiné zone (French Alps): the record of Alpine collision and implications for pre-Alpine restoration. Swiss J. Geosci. 101, 89-110. doi:10.1007/s00015-008-1280-2

Dumont, T., Simon-Labric, T., Authemayou, C., Heymes, T., 2011. Lateral termination of the north-directed Alpine orogeny and onset of westward escape in the Western Alpine arc: Structural and sedimentary evidence from the external zone: FROM NORTH TO WEST DIRECTED OROGENY, WESTERN ALPS. Tectonics 30, n/a-n/a. doi:10.1029/2010TC002836

Ellenberger, F., 1958. Etude géologique du pays de Vanoise. Impr. nationale.

Ellenberger, F., 1952. Sur l'extension des faciès Briançonnais en Suisse, dans les Préalpes médianes et les Pennides. Eclogae Geol. Helvetiae 45, 285-286.

Faure, J.L., Mégard-Galli, J., 1988. L'émersion jurassique en Briançonnais, sédimentation continnetale et fracturation distensive. Bull. Soc. Geol. Fr. IV, 681-692.

Florineth, D., Froitzheim, N., 1994. TRANSITION FROM CONTINENTAL TO OCEANIC BASEMENT IN THE TASNA NAPPE (ENGADINE WINDOW, GRAUBUNDEN, SWITZERLAND)-EVIDENCE FOR EARLY CRETACEOUS OPENING OF THE VALAIS OCEAN. Schweiz. Mineral. Petrogr. Mitteilungen 74, 437448.

Franke, D., 2013. Rifting, lithosphere breakup and volcanism: comparison of magma-poor and volcanic rifted margins. Mar. Pet. Geol. 43, 63-87.

Froitzheim, N., Rubatto, D., 1998. Continental breakup by detachment faulting: field evidence and geochronological constraints (Tasna nappe, Switzerland). Terra Nova 10, 171-176.

Funck, T., Hopper, J.R., Larsen, H.C., Louden, K.E., Tucholke, B.E., Holbrook, W.S., 2003. Crustal structure of the ocean-continent transition at Flemish Cap: Seismic refraction results. J. Geophys. Res. Solid Earth 1978-2012 108. 
Gaina, C., Müller, R.D., Brown, B., Ishihara, T., Ivanov, S., 2007. Breakup and early seafloor spreading between India and Antarctica. Geophys. J. Int. 170, 151-169.

Gillard, M., Autin, J., Manatschal, G., Sauter, D., Munschy, M., Schaming, M., 2015. Tectonomagmatic evolution of the final stages of rifting along the deep conjugate Australian-Antarctic magma-poor rifted margins: Constraints from seismic observations. Tectonics 34, 753-783.

Gillcrist, R., Coward, M., Mugnier, J.-L., 1987. Structural inversion and its controls: examples from the Alpine foreland and the French Alps. Geodin. Acta 1, 5-34.

Group, T.E.-C.G., Bayer, R., Carozzo, M.T., Lanza, R., Miletto, M., Rey, D., 1989. Gravity modelling along the ECORS-CROP vertical seismic reflection profile through the Western Alps. Tectonophysics 162, 203-218.

Gürler, B., 1995. Geologische Untersuchungen im SW-Teil des Unterengadiner Fensters: Teil I Geologie der Val Tasna und Umgebung; Beiträge zur Geologischen Karte der Schweiz, NF 166, 72 pp.

Hopper, J.R., Funck, T., Tucholke, B.E., Larsen, H.C., Holbrook, W.S., Louden, K.E., Shillington, D., Lau, H., 2004. Continental breakup and the onset of ultraslow seafloor spreading off Flemish Cap on the Newfoundland rifted margin. Geology 32, 93-96.

Huismans, R., Beaumont, C., 2011. Depth-dependent extension, two-stage breakup and cratonic underplating at rifted margins. Nature 473, 74-78.

Huismans, R.S., Beaumont, C., 2002. Asymmetric lithospheric extension: The role of frictional plastic strain softening inferred from numerical experiments. Geology 30, 211. doi:10.1130/00917613(2002)030<0211:ALETRO>2.0.CO;2

Jaillard, E., 1985. Evolutions sédimentaire et paléotectonique de la zone briançonnaise de vanoise occidentale (Alpes occidentales françaises). Géologie Alp. 61.

Jammes, S., Lavier, L., Manatschal, G., 2010. Extreme crustal thinning in the Bay of Biscay and the Western Pyrenees: From observations to modeling. Geochem. Geophys. Geosystems 11.

Karner, G.D., Driscoll, N.W., 1999. Tectonic and stratigraphic development of the West African and eastern Brazilian Margins: insights from quantitative basin modelling. Geol. Soc. Lond. Spec. Publ. 153, 11-40.

Karner, G.D., Watts, A.B., 1982. On isostasy at Atlantic-type continental margins. J. Geophys. Res. Solid Earth 1978-2012 87, 2923-2948.

Kohn, B.P., Eyal, M., 1981. History of uplift of the crystalline basement of Sinai and its relation to opening of the Red Sea as revealed by fission track dating of apatites. Earth Planet. Sci. Lett. 52, 129-141.

Lau, K.W., Louden, K.E., Funck, T., Tucholke, B.E., Holbrook, W.S., Hopper, J.R., Christian Larsen, H., 2006. Crustal structure across the Grand Banks-Newfoundland Basin Continental Margin-I. Results from a seismic refraction profile. Geophys. J. Int. 167, 127-156.

Lavier, L.L., Manatschal, G., 2006. A mechanism to thin the continental lithosphere at magma-poor margins. Nature 440, 324-328. doi:10.1038/nature04608

Lefèvre, R., Michard, A., 1976. Les nappes briançonnaises internes et ultra-briançonnaises de la bande d'Acceglio (Alpes franco-italiennes); une étude structurale et pétrographique dans le faciès des schistes bleus à jadéite. Sci. Géologiques Bull. Strasbg. 29, 183-222.

Lemoine, M., 1967. Brèches sédimentaires marines à la frontière entre les domaines briançonnais et piémontais dans les Alpes occidentales. Geol. Rundsch. 56, 320-335.

Lemoine, M., 1961. La marge externe de la fosse piémontaise dans les Alpes occidentales. Rev Géogr Phys Géol Dyn 2, 163-180.

Lemoine, M., 1960. Présence de flyschs exotiques liés à la quatrième écaille près Briançon.pdf 3.

Lemoine, M., Bas, T., Arnaud-Vanneau, A., Arnaud, H., Dumont, T., Gidon, M., Bourbon, M., de Graciansky, P.-C., Rudkiewicz, J.-L., Megard-Galli, J., others, 1986. The continental margin of the Mesozoic Tethys in the Western Alps. Mar. Pet. Geol. 3, 179-199. 
Lemoine, M., Tricart, P., 1988. Queyras: un océan il ya 150 millions d'années: initiation à la géologie sur les sentiers du Queyras. Parc naturel régional du Queyras.

Lemoine, M., Tricart, P., Boillot, G., 1987. Ultramafic and gabbroic ocean floor of the Ligurian Tethys (Alps, Corsica, Apennines): In search of a genetic imodel. Geology 15, 622. doi:10.1130/00917613(1987)15<622:UAGOFO>2.0.CO;2

Lemoine, M., Trümpy, R., 1987. Pre-oceanic rifting in the Alps. Tectonophysics 133, 305-320.

Lister, G.S., Etheridge, M.A., Symonds, P.A., 1986. Detachment faulting and the evolution of passive continental margins. Geology 14, 246. doi:10.1130/0091-7613(1986)14<246:DFATEO>2.0.CO;2

Manatschal, G., 2004. New models for evolution of magma-poor rifted margins based on a review of data and concepts from West Iberia and the Alps. Int. J. Earth Sci. 93, 432-466.

Manatschal, G., Engström, A., Desmurs, L., Schaltegger, U., Cosca, M., Müntener, O., Bernoulli, D., 2006. What is the tectono-metamorphic evolution of continental break-up: the example of the Tasna Ocean-Continent Transition. J. Struct. Geol. 28, 1849-1869.

Manatschal, G., Lavier, L., Chenin, P., 2015. The role of inheritance in structuring hyperextended rift systems: Some considerations based on observations and numerical modeling. Gondwana Res. 27, 140-164.

Manatschal, G., Müntener, O., 2009. A type sequence across an ancient magma-poor ocean-continent transition: the example of the western Alpine Tethys ophiolites. Tectonophysics 473, 4-19. doi:10.1016/j.tecto.2008.07.021

Manatschal, G., Müntener, O., Lavier, L.L., Minshull, T.A., Péron-Pinvidic, G., 2007. Observations from the Alpine Tethys and Iberia-Newfoundland margins pertinent to the interpretation of continental breakup. Geol. Soc. Lond. Spec. Publ. 282, 291-324.

Mangipudi, V.R., Goli, A., Desa, M., Tammisetti, R., Dewangan, P., 2014. Synthesis of deep multichannel seismic and high resolution sparker data: Implications for the geological environment of the Krishna-Godavari offshore, Eastern Continental Margin of India. Mar. Pet. Geol. 58, 339-355. doi:10.1016/j.marpetgeo.2014.08.006

Masini, E., Manatschal, G., Mohn, G., 2013. The Alpine Tethys rifted margins: Reconciling old and new ideas to understand the stratigraphic architecture of magma-poor rifted margins. Sedimentology 60, 174-196. doi:10.1111/sed.12017

Masini, E., Manatschal, G., Mohn, G., Unternehr, P., 2012. Anatomy and tectono-sedimentary evolution of a rift-related detachment system: The example of the Err detachment (central Alps, SE Switzerland). Geol. Soc. Am. Bull. 124, 1535-1551.

Masson, H., Baud, A., Escher, A., Gabus, J., Marthaler, M., 1980. Compte rendu de l'excursion de la Société Géologique Suisse du 1 au 3 octobre 1979: coupe Préalpes-Helvétique-Pennique en Suisse occidentale. Eclogae Geol Helv 7371, 331-349.

McKenzie, D., 1978. Some remarks on the development of sedimentary basins. Earth Planet. Sci. Lett. 40, 25-32.

Minshull, T.A., Dean, S.M., Whitmarsh, R.B., Russell, S.M., Louden, K.E., Chian, D., Group, D. 215 W., 1998. Deep structure in the vicinity of the ocean-continent transition zone under the southern Iberia Abyssal Plain. Geology 26, 743-746.

Mohn, G., 2010. L'évolution tectono-sédimentaire des marges de la Téthys Alpine au cours de l'amincissement lithosphérique. Université de Strasbourg, Strasbourg.

Mohn, G., Karner, G.D., Manatschal, G., Johnson, C.A., 2015. Structural and stratigraphic evolution of the Iberia-Newfoundland hyper-extended rifted margin: a quantitative modelling approach. Geol. Soc. Lond. Spec. Publ. doi:10.1144/SP413.9

Mohn, G., Manatschal, G., Beltrando, M., Haupert, I., 2014. The role of rift-inherited hyper-extension in Alpine-type orogens. Terra Nova 26, 347-353. doi:10.1111/ter.12104 
Mohn, G., Manatschal, G., Beltrando, M., Masini, E., Kusznir, N., 2012. Necking of continental crust in magma-poor rifted margins: Evidence from the fossil Alpine Tethys margins. Tectonics 31.

Muto, T., \& Steel, R. J. (2000). The accommodation concept in sequence stratigraphy: some dimensional problems and possible redefinition. Sedimentary Geology, 130(1), 1-10.

Nemcok, M., Sinha, S.T., Stuart, C.J., Welker, C., Choudhuri, M., Sharma, S.P., Misra, A.A., Sinha, N., Venkatraman, S., 2013. East Indian margin evolution and crustal architecture: integration of deep reflection seismic interpretation and gravity modelling. Geol. Soc. Lond. Spec. Publ. 369, 477496. doi:10.1144/SP369.6

Pateria, M.L., Rangaraju, M.K., Raiverman, V., 1992. A note on the structure and stratigraphy of Bay of Bengal sediments. Recent Geosci. Stud. Bay Bengal Andaman Sea Geol Surv India Spec Publ 29, 21-23.

Peron-Pinvidic, G., Manatschal, G., 2010. From microcontinents to extensional allochthons: witnesses of how continents rift and break apart? Pet. Geosci. 16, 189-197. doi:10.1144/1354-079309-903

Péron-Pinvidic, G., Manatschal, G., 2009. The final rifting evolution at deep magma-poor passive margins from Iberia-Newfoundland: a new point of view. Int. J. Earth Sci. 98, 1581-1597. doi:10.1007/s00531-008-0337-9

Péron-Pinvidic, G., Manatschal, G., Minshull, T.A., Sawyer, D.S., 2007. Tectonosedimentary evolution of the deep Iberia-Newfoundland margins: Evidence for a complex breakup history. Tectonics 26, TC2011.

Peron-Pinvidic, G., Manatschal, G., Osmundsen, P.T., 2013. Structural comparison of archetypal Atlantic rifted margins: a review of observations and concepts. Mar. Pet. Geol. 43, 21-47.

Peron-Pinvidic, G., Manatschal, G., Masini, E., Sutra, E., Flament, J. M., Haupert, I., \& Unternehr, P. (2015, April). The Angola-Gabon rifted margin: reappraisal of the upper-and lower-plate concept. In EGU General Assembly Conference Abstracts (Vol. 17, p. 5164).

Pindell, J.L., Kennan, L., 2009. Tectonic evolution of the Gulf of Mexico, Caribbean and northern South America in the mantle reference frame: an update. Geol. Soc. Lond. Spec. Publ. 328, 1-55.

Powell, C.M., Roots, S.R., Veevers, J.J., 1988. Pre-breakup continental extension in East Gondwanaland and the early opening of the eastern Indian Ocean. Tectonophysics 155, 261-283.

Pubellier, M., Ali, J., Monnier, C., 2003. Cenozoic Plate interaction of the Australia and Philippine Sea Plates:"hit-and-run" tectonics. Tectonophysics 363, 181-199.

Pubellier, M., Ego, F., 2002. Anatomy of an escape tectonic zone: Western Irian Jaya (Indonesia). Tectonics 21, 1-1-1-16.

Ranero, C.R., Pérez-Gussinyé, M., 2010. Sequential faulting explains the asymmetry and extension discrepancy of conjugate margins. Nature 468, 294-299.

Ranero, C.R., von Huene, R., Weinrebe, W., Reichert, C., 2006. Tectonic processes along the Chile convergent margin, in: The Andes. Springer, pp. 91-121.

Reston, T.J., 2009. The structure, evolution and symmetry of the magma-poor rifted margins of the North and Central Atlantic: A synthesis. Tectonophysics 468, 6-27. doi:10.1016/j.tecto.2008.09.002

Reston, T.J., 2007. The formation of non-volcanic rifted margins by the progressive extension of the lithosphere: the example of the West Iberian margin. Geol. Soc. Lond. Spec. Publ. 282, 77-110. doi:10.1144/SP282.5

Reston, T.J., McDermott, K.G., 2011. Successive detachment faults and mantle unroofing at magma-poor rifted margins. Geology 39, 1071-1074.

Reston, T.J., Ranero, C.R., 2011. The 3-D geometry of detachment faulting at mid-ocean ridges. Geochem. Geophys. Geosystems 12.

Reynolds, S.J., Spencer, J.E., 1985. Evidence for large-scale transport on the Bullard detachment fault, west-central Arizona. Geology 13, 353-356. 
Robertson, A.H.F., 2007. Continental break-up of the Newfoundland rifted margin (ODP Leg 210): L. Cretaceous seafloor formed by exhumation of subcontinental mantle lithosphere and the transition to seafloor spreading, in: Geophysical Research Abstracts. p. 11343.

Roux, M., Bourseau, J.-P., Bas, T., Dumont, T., de Graciansky, P.-C., Lemoine, M., Rudkiewicz, J.-L., 1988. Bathymetric evolution of the Tethyan margin in the western Alps (data from stalked crinoids): a reappraisal of eustatism problems during the Jurassic. Bull. Société Géologique Fr. 4, 633-641.

Schneegans, D., 1933. Sur la découverte de nouveaux gisements de Diplopores (Algues calcaires) dans le Trias de la zone du Briançonnais. Allier Père et Fils.

Schwizer, B., 1983. Die Tristel Formation-Vergleichende Un- tersuchung in Graubiinden, Liechtenstein, Vorarlberg and Bayem, Unpubl. Ph.D. Diss., Univ. Bern, Bern, 185 pp.

Shillington, D.J., Holbrook, W.S., Van Avendonk, H.J.A., Tucholke, B.E., Hopper, J.R., Louden, K.E., Larsen, H.C., Nunes, G.T., 2006. Evidence for asymmetric nonvolcanic rifting and slow incipient oceanic accretion from seismic reflection data on the Newfoundland margin. J. Geophys. Res. 111, B09402.

Sibuet, J.-C., Ryan, W.B., 1979. Site 398: evolution of the west Iberian passive continental margin in the framework of the early evolution of the North Atlantic Ocean. Initial Rep. Deep Sea Drill. Proj. 67, 673-687.

Stampfli, G.M., Marcoux, J., Baud, A., 1991. Tethyan margins in space and time. Paleogeography Paleoclimatology Palaeoecol. 87, 373-409.

Storey, M., Mahoney, J.J., Saunders, A.D., Duncan, R.A., Kelley, S.P., Coffin, M.F., 1995. Timing of hot spot-related volcanism and the breakup of Madagascar and India. Science 267, 852-855.

Subrahmanyam, C., Chand, S., 2006. Evolution of the passive continental margins of India-a geophysical appraisal. Gondwana Res. 10, 167-178.

Sutra, E., Manatschal, G., 2012. How does the continental crust thin in a hyperextended rifted margin? Insights from the Iberia margin. Geology 40, 139-142.

Sutra, E., Manatschal, G., Mohn, G., Unternehr, P., 2013. Quantification and restoration of extensional deformation along the Western Iberia and Newfoundland rifted margins: Strain Distribution Along Rifted Margins. Geochem. Geophys. Geosystems 14, 2575-2597. doi:10.1002/ggge.20135

Termier, P., 1903. Quatre coupes à travers les Alpes Franco-Italiennes. Bull. Société Géologique Fr. 2, 411433.

Tricart, P., Van der Beek, P., Schwartz, S., Labrin, E., 2007. Diachronous late-stage exhumation across the western Alpine arc: constraints from apatite fission-track thermochronology between the Pelvoux and Dora-Maira Massifs. J. Geol. Soc. 164, 163-174.

Trümpy, R., 1980. Geology of Switzerland: An outline of the geology of Switzerland. Interbook.

Tucholke, B.E., Sibuet, J.-C., 2007. Leg 210 synthesis: tectonic, magmatic, and sedimentary evolution of the Newfoundland-Iberia rift, in: Proceedings of the Ocean Drilling Program, Scientific Results. Ocean Drilling Program College Station, TX, pp. 1-56.

Tucholke, B.E., Sibuet, J.C., Klaus, A., 2004. 1. Leg 210 Summary, in: Proc. Ocean Drill. Program, Initial Rep. pp. 1-78.

Tugend, J., Manatschal, G., Kusznir, N.J., 2015. Spatial and temporal evolution of hyperextended rift systems: Implication for the nature, kinematics, and timing of the Iberian-European plate boundary. Geology 43, 15-18.

Van Avendonk, H.J.A., Lavier, L.L., Shillington, D.J., Manatschal, G., 2009. Extension of continental crust at the margin of the eastern Grand Banks, Newfoundland. Tectonophysics 468, 131-148.

Van Avendonk, H.J., Holbrook, W.S., Nunes, G.T., Shillington, D.J., Tucholke, B.E., Louden, K.E., Larsen, H.C., Hopper, J.R., 2006. Seismic velocity structure of the rifted margin of the eastern Grand Banks of Newfoundland, Canada. J. Geophys. Res. Solid Earth 1978-2012 111. 
Vanossi, M., 1965. Studio sedimentologico del flysch ad elmintoidi della valle Argentina (Liguri occidentale). Tipografia del libro.

Waibel, A.F., Frisch, W., 1989. The Lower Engadine Window: sediment deposition and accretion in relation to the plate-tectonic evolution of the Eastern Alps. Tectonophysics 162, 229-241.

Wernicke, B., 1985. Uniform-sense normal simple shear of the continental lithosphere. Can. J. Earth Sci. 22, 108-125.

Wernicke, B., 1981. Low-angle normal faults in the Basin and Range Province: nappe tectonics in an extending orogen. Nature 291, 645-648.

Wernicke, B., Burchfiel, B.C., 1982. Modes of extensional tectonics. J. Struct. Geol. 4, 105-115.

White, W.M., Duncan, R.A., 1996. Geochemistry and geochronology of the Society Islands: new evidence for deep mantle recycling. Geophys. Monogr.-Am. Geophys. UNION 95, 183-206.

Whitmarsh, R.B., Sawyer, D.S., 1996. The ocean/continent transition beneath the Iberia Abyssal Plain and continental-rifting to seafloor-spreading processes, in: PROCEEDINGS-OCEAN DRILLING PROGRAM SCIENTIFIC RESULTS. NATIONAL SCIENCE FOUNDATION, pp. 713-736.

Wilson, R.C.., Manatschal, G., Wise, S., 2001. Rifting along non-volcanic passive margins : stratigraphic and seismic evidence from th eMesozoic successions of the Alps and western Iberia. Geol. Soc. Lond. Spec. Publ. 429-452. 